\title{
NHÀ VĂN HÓA TRONG ĐỜI SỐNG NÔNG THÔN VIẸTT NAM
}

\author{
NGUYẼ̃N THỊ THÚY NGÂN \\ KHÓA LUẠN TÔT NGHIẸP NGÀNH VIẸT NAM HOC \\ KHOA VIỆT NAM HỌC VÀ TIÉNG VIẸT \\ TRƯỜNG ĐẠI HỌC KHOA HỌC XÃ HộI VÀ NHÂN VĂN
}

ĐẠI HỌC QUỐC GIA HÀ NộI - 2016 


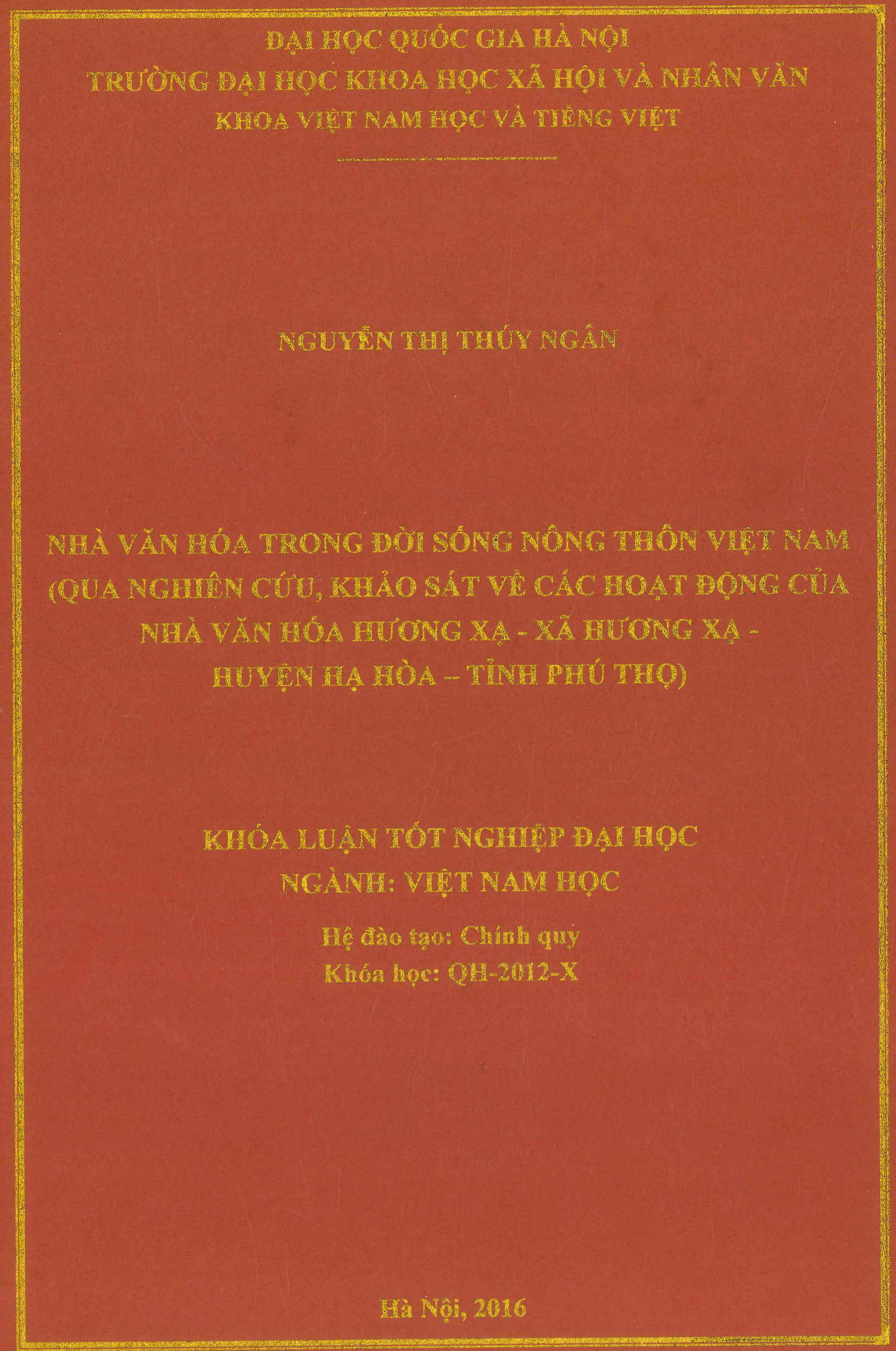


ĐẠI HỌC QUỐC GIA HÀ NộI

TRƯÒNG ĐẠI HỌC KHOA HỌC XÃ HỘI VÀ NHÂN VĂN

KHOA VIẸTT NAM HỌC VÀ TIẾNG VIẸTT

NGUYẼ̃ TH!̣ THÚY NGÂN

NHÀ VĂN HÓA TRONG ĐỜI SỐNG NÔNG THÔN VIẸTT NAM (QUA NGHIÊN CÚU, KHẢO SÁT VỀ CÁC HOẠT ĐỘNG CỦA NHÀ VĂN HÓA HƯỚ XẠ - XÃ HƯỚNG XẠ -

HUYẸN HẠ HÒA - TỈNH PHÚ THỌ)

\section{KHÓA LUẬN TỐT NGHIỆP ĐẠI HỌC NGÀNH: VIẸTT NAM HỌC}

Hệ đào tạo: Chính quy

Khóa học: QH-2012-X

Giáo viên hướng dẫn: TS. Đặng Thị Vân Chi

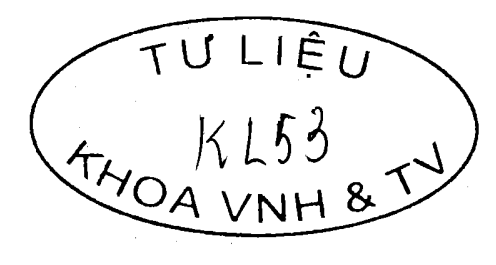

Hà Nội, 2016 


\section{LỜI CAM ĐOAN}

Tôi xin cam đoan đề tài khóa luận "Nhà văn hóa trong đời sống nông thôn Việt Nam - qua nghiên cứu, khảo sát về các hoạt động của nhà văn hóa Hương Xạ - xã Hương Xạ - huyện Hạ Hòa - tỉnh Phú Thọ” là hoàn toàn do tôi thực hiện. Các đoạn trích dẫn và số liệu sử dụng trong khóa luận đều được dẫn nguồn có độ chính xác cao nhất trong phạm vi hiểu biết của tôi.

Hà Nội, ngày 16 tháng 05 năm 2016

Sinh viên

Nguyễn Thị Thúy Ngân 
ĐạI HỌC QUỐC GIA HÀ NộI

ĐẠI HỌC KHOA HỌC XÃ HộI VÀ NHÂN

VĂN
CộNG HOÀ XÃ HỘI CHỦ NGHĨA VIỆT NAM

Đốc lâp - Tư do-Hanh phúc

KHOA VIỆT NAM HỌC VÀ TIẾNG VIỆT

\section{ĐỂ TÀI KHÓA LUẬN TỐT NGHIỆP ĐẠI HỌC}

Họ và tên sinh viên: Nguyễn Thị Thúy Ngân

Lớp: K57 Việt Nam học

Ngành đào tạo:Việt Nam học
Khoá: QH-2012-X

Hệ đào tạo: Đại học chính quy

\section{1/ Tên khóa luận tốt nghiệp}

"Nhà văn hóa trong đời sống nông thôn Việt Nam - qua việc nghiên cứu, khảo sát về các hoạt động của nhà văn hóa Hương Xạ - xã Hương Xạ - huyện Hạ Hòa - tỉnh Phú Thọ"

\section{2/ Nội dung chính của khóa luận}

Chương 1.Tổng quan làng Hương Xạ, xã Hương Xạ - huyện Hạ Hòa tỉnh Phú Thọ

Chương 2. Nhà văn hoá Hương Xạ - huyện Hạ Hoà - tỉnh Phú Thọ

Chương 3: Hoạt động của Nhà văn hoá Hương Xạ và những vấn đề đặt ra 3/Ngày nộp khóa luận : 19/5/2016

SINH VIÊN

(Ký, ghi rõ họ tên)
GIÁO VIÊN HƯớNG DÃN (duyệt)

(Ký, ghi rõ họ tên) 


\section{LÒ̀I CẢM ONN}

Được sự cho phép của khoa Việt Nam học và Tiếng Việt, trường Đại học Khoa học Xã hội và Nhân văn, Đại học Quốc gia Hà Nội, và sự đồng ý của cô giáo hướng dẫn TS. Đặng Thị Vân Chi tôi đã thực hiện đê tài "Nhà văn hóa trong đời sống nông thôn Việt Nam - qua việc nghiên cứu, khảo sát về các hoạt động của nhà văn hóa Hương Xạ - xã Hương Xạ - huyện Hạ Hòa tỉnh Phú Thọ".

Để hoàn thành khóa luận này, tôi xin chân thành cảm ơn các thầy, cô giáo đã tận tình hướng dẫn, giảng dạy trong suốt quá trình học tập, nghiên cứu và rèn luyện tại trường Đại học Khoa học Xã hội và Nhân văn, Đại học Quốc gia Hà Nội.

Tôi xin chân thành cảm ơn cô giáo hướng dẫn TS. Đặng Thị Vân Chi đã tận tình, chu đáo hướng dẫn tôi thực hiện khóa luận này.

Mặc dù đã có nhiều cố gắng để thực hiện đề tài một cách hoàn chỉnh nhất, song do buổi đầu mới làm quen với công tác nghiên cứu khoa học, tiếp cận thực tế cũng như những hạn chế về kiến thức và kinh nghiệm nên không thể tránh khỏi những thiếu sót nhất định mà bản thân chưa thấy được. Tôi rất mong nhận được sự đóng góp của quý thầy cô giáo cùng toàn thể các bạn để khóa luận được hoàn chỉnh hơn.

Tôi xin chân thành cám ơn!

Hà nội, ngày 16 tháng 5 năm 2016

\section{Sinh viên}




\section{MỤC LỤC}

MỞ ĐẦ .4

1. Lý do chọn đề tài 4

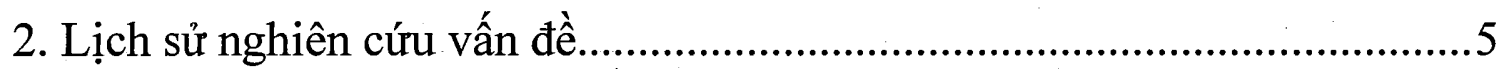

3. Đối tượng nghiên cứu.........................................................................

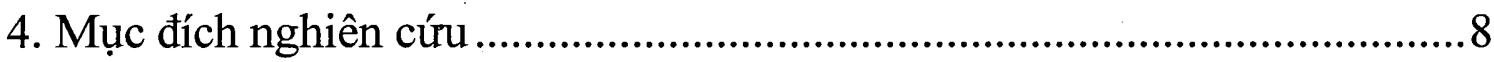

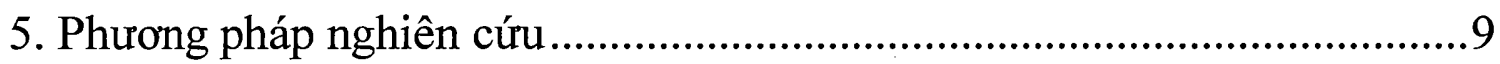

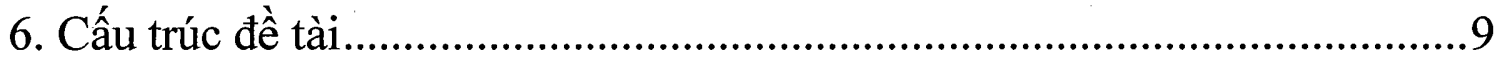

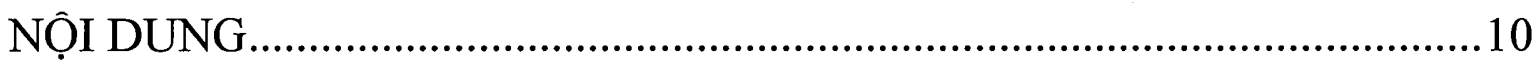

Chương 1. TỖNG QUAN LÀNG HƯONG XẠ, XÃ HƯONG XẠ - HUYỆN HẠ HÒA - TỈNH PHÚ THỌ ................................................................. 10

1.1. Vị trí địa lý, điều kiện tự nhiên và môi trường sinh thái........................10

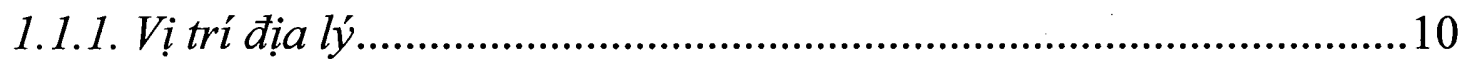

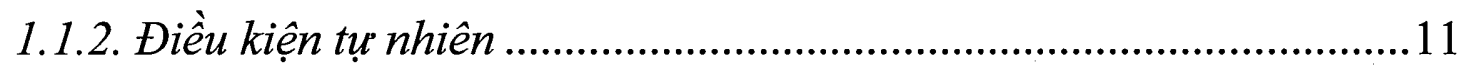

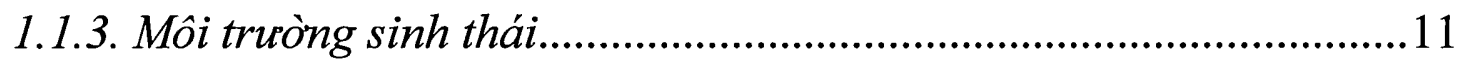

1. 2. Quá trình hình thành và phát triểncủa làng Hương Xạ .........................12

1.2.1. Lịch sủ hình thành và sụ thay đổi đơn vị hành chính làng Hưong Xạ. .12

1.2.2. Làng Hưong Xạ trong các giai đoạn lịch sủ...................................13

1.2.2.1. Làng Hương Xạ từ khi thành lập đến năm 1945........................13

1.2.2.2. Hương $X a$ tù̀ 1945 đến 1954 ..................................................... 18

1.2.2.3. Hương Xạ từ 1955 đến1986......................................................19

1.2.2.4. Hương Xạ từ 1986 đến nay .......................................................21

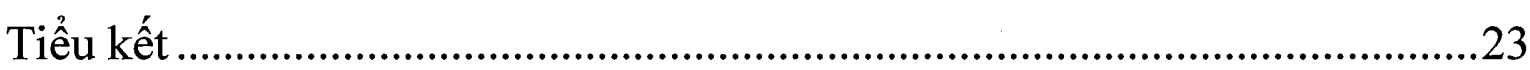

Chương 2. NHÀ VĂN HOÁ HƯƠNG XẠ - HUYỆN HẠ HOÀ....................25

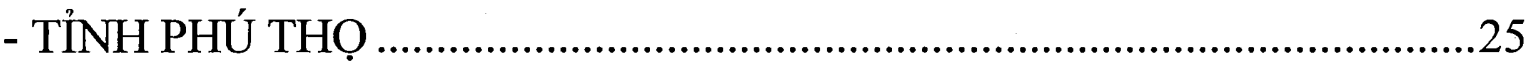

2.1. Chủ trương của Đảng và Nhà nước về xây dựng nhà văn hoá trong chương trình xây dựng nông thôn mới .........................................................25

2.2. Nhà văn hoá Hương Xạ ..........................................................................33

2.2.1. Đời sống văn hóa của cu dân Hương Xạ truớc khi có nhà văn hóa 
2.2.2. Triển khai xây dụng nhà văn hoá Hương Xạ theo quy định của Nhà nước

2.3.2. Quá trình xây dụng nhà văn hoá Huơng Xạ..................................38

Tiểu kết

Chương 3: HOẠT ĐộNG CỦA NHÀ VĂN HOÁ HƯƠNG XẠ VÀ NHŨNA

VÂN ĐỀ ĐẠTT RA

3.1. Về cơ chế quản lý, tổ chức các hoạt động. 44

3.2. Hoạt động của nhà văn hoá Hương Xạ 45

3.2.1. Tổ chức phổ biến đường lối chính sách của Đảng và nhà nước đến nhân dân 48

3.2.2. Tổ chức triển khai các nghị quyết của Đảng và Nhà nuớc cũng nhu chính quyền địa phưong 48

3.2.3. Tổ chức các cuộc họp thảo luận về các vấn đề liên quạn đến cuộc sống của cu dân. 49

3.2.4. Tổ chức các cuộc hội họp của các đoàn thể 50

3.2.5. Tổ chức các hoạt động kỷ niệm, ngày lễ. 50

3.2.6. Tổ chức các cuộc sinh hoạt văn hoá, nghệ thuật .51

3.2.7. Tổ chức các cuộc thi đấu thể dục, thể thao 52

3.2.8. Các hoạt động khác 52

3.3. Bước đầu đánh giá về hoạt động của nhà văn hóa Hương Xạ 53

3.4. Những tồn tại của nhà văn hóa Hương Xạ .55

Các cán bộ lãnh đạo cấp trên chưa có những quy định chặt chẽ trong việc quản lý và sử dụng nhà văn hoá. 56

3.5. Kiến nghị của người dân: 56

3.6. Các giải pháp nâng cao hiệu quả hoạt động của nhà văn hóa 57 Tiểu kết .60

KẾT LUẬN 61

PHỤ LỤC .62 


\section{DANH MỤC TỪ VIẾT TÁ́T}

UBND: $\quad$ Ủy ban nhân dân

UBMTTQ: Ủy ban Mặt trận Tổ quốc

UB: Ủy ban

HTX: $\quad$ Hợp tác xã

BVHTT\&DL: Ban Văn hóa Thể thao và Du lịch

QĐ: $\quad$ Quyết định

NĐ: $\quad$ Nghị quyết

TW: $\quad$ Trung ương

ĐCS: $\quad$ Đảng Cộng sản 


\section{MỞ ĐẦU}

\section{Lý do chọn đề tài}

Việt Nam là là một nước nông nghiệp, hầu hết cư dân Việt Nam đều sinh sống trong các làng xã ở khu vực nông thôn. Do những đặc điểm về điều kiện tự nhiên, môi trường sinh thái cùng với việc chọn cây lúa nước và nền kinh tế nông nghiệp tiểu nông là ngành kinh tế chủ đạo, người nông dân Việt Nam đã sớm biết dựa vào nhau, gắn bó và liên kết với nhau để cùng tồn tại và phát triển. Cùng với thời gian, người dân trong các làng xã đã xây dựng nên một ý thức cộng đồng bền chặt. Hầu hết các nhà nghiên cứu lịch sử và văn hóa Việt Nam đều thống nhất cho rằng ý thức cộng đồng làng xã là một trong những đặc diểm nổi bật của làng xã Việt Nam. Trong các làng xã Việt Nam truyền thống, đình làng là nơi sinh hoạt cộng đồng, nơi diễn ra các hoạt động chung của người dân trong làng: từ những hoạt động có tính chính trị, hành chính (nơi họp hành, bàn việc làng của các Hội đồng Kỳ mục của làng, nơi giải quyết các tranh chấp, các vụ vi phạm lệ làng, phép nước), đến các hoạt động tôn giáo, tín ngưỡng (thờ cúng Thành hoàng làng), văn hóa (Hội làng, chiếu Chèo...)

Tuy nhiên, từ sau Cách mạng tháng Tám năm 1945, đặc biệt từ năm 1954, nông thôn miền Bắc có nhiều thay đổi, trong các làng xã, hầu hết các ngôi đình làng hoặc bị phá hủy, hoặc được sử dụng vào những mục đích khác. Các hợp tác xã nông nghiệp và công cuộc tập thể hóa nông nghiệp đã thay đổi nếp sinh hoạt cộng đồng của người dân nông thôn. Kể từ sau Đổi mới, đời sống nông thôn Việt Nam đã có sự chuyển biến mạnh mẽ cùng với sự phát triển của đất nước, đặc biệt là với chương trình xây dựng nông thôn mới, bên cạnh những thay đổi về cơ sở hạ tầng, hệ thống đèn điện chiếu sáng, bê tông hóa đường làng, ngõ xóm,... các ngôi nhà văn hóa theo phong cách hiện đại được dựng lên và trở thành không gian sinh hoạt văn hóa cộng đồng của người dân làng xã được nhà nước và chính quyền địa phương quan tâm đầu tư xây dựng. 
Trong chủ trương xây dựng nông thôn mới của Đảng và Nhà nước, nhà văn hóa là một bộ phận quan trọng góp phần đẩy mạnh nếp sống văn hóa trong khu dân cư, nâng cao hiệu quả xây dựng làng văn hóa, gia đình văn hóa. Tuy nhiên, việc xây dựng và sử dụng nhà văn hóa như thế nào để có thể phát huy hết vai trò như trung tâm sinh hoạt văn hóa cộng đồng ở nông thôn là một vấn đề đang đặt ra ở mỗi địa phương trong cả nước.

Hiện nay, ở khu vực nông thôn, hầu hết các làng quê đều có nhà văn hóa. Nhà văn hóa không chỉ được xây dựng ở cấp độ xã, mà nhiều nơi, các xóm cũng có nhà văn hóa rất khang trang. Tuy nhiên, việc sử dụng hiệu quả và phát huy vai trò của các nhà văn hóa trong việc xây dựng nông thôn mới, cũng như nâng cao đời sống văn hóa tinh thần của ngươi dân nông thôn đang đặt ra nhiều vấn đề cần phải giải quyết. Vì vậy, việc nghiên cứu, tìm hiểu vai trò, hiện trạng của nhà văn hóa trong đời sống nông thôn Việt Nam hiện nay là một vấn đề quan trọng góp phần nhận thức rõ hơn về vai trò của nhà văn hóa trong đời sống nông thôn Việt Nam, cũng như làm thế nào có thể phát huy tối đa vai trò của nhà văn hóa trong việc xây dựng nông thôn mới. Từ việc tìm hiểu vai trò và hiện trạng của các nhà văn hóa ở khu vực nông thôn hiện nay, tôi mong muốn có thể đưa ra những giải pháp, nhằm nâng cao hơn nữa vai trò và hiệu quả của các nhà văn hóa trong việc nâng cao đời sống văn hóa tinh thần của cư dân nông thôn hiện nay. Chính vì lý do đó, tôi chọn đề tài nghiên cứu là "Nhà văn hóa trong đời sống nông thôn Việt Nam - qua việc nghiên cứu, khảo sát về các hoạt động của nhà văn hóa Hương Xạ - xã Hương Xạ - huyện Hạ Hòa - tỉnh Phú Thọ" làm đề tài khóa luận của mình.

\section{Lịch sử nghiên cứu vấn đề}

Vấn đề nghiên cứu làng xã nông thôn Việt Nam từ xưa đến nay luôn là đề tài hấp dẫn. Đặc biệt, từ khi thực hiện chủ trương, đường lối của Đảng và chính sách, pháp luật của Nhà nước về phát triển nông thôn mới thì lĩnh vực này càng nhận được sự quan tâm của nhiều nhà nghiên cứu, nhiều nhà hoạt 
động văn hóa. Chính vì vậy, từ xưa đến nay đã có nhiều công trình nghiên cứu vấn đề này trên nhiều phương diện:

Thứ nhất, nghiên cứu tổng quan về vấn đề làng xã Việt Nam nói chung, tiêu biểu có các công trình:

- “Một số vấn đề về làng xã Việt Nam” của GS.TS Nguyễn Quang Ngọc.

- Tác phẩm “Làng văn hóa cổ truyền Việt Nam” của GS.Vũ Ngọc Khánh, NXB Văn học

- “Cộng đồng làng xã Việt Nam” của TS. Nguyễn Văn Sáu.

Thứ hai, nghiên cứu về những thành tựu phát triển kinh tế và văn hóa trong những năm đổi mới, tiêu biểu như các công trình:

- "Việt Nam đất nước con người - thành tưu 70 xây dưng và phát triển (1945-2015)" - Thông tấn xã Việt Nam, NXB Thông tấn

-"Kinh tế Việt Nam thăng trầm và đột phá”, của Phạm Minh Chính, Vương Quân Hoàng, NXB Chính trị quốc gia.

- "Đối diện thách thức tái cơ cấu kinh tế" của TS. Nguyễn Đức Thành, NXB Đại học quốc gia Hà Nội

Thứ ba, các công trình nghiên cứu sâu về văn hóa, tôn giáo, tín ngưỡng trong thời kỳ đổi mới, tiêu biểu như:

- "Thực trạng, giải pháp xây dụng nền văn hóa Việt Nam trong thời kỳ đổi mới”, Kỷ yếu hội thảo, tổ chức tại Ban VHTTDL ngày 15-5-2013; Bộ văn hóa Thể thao và Du lịch

- "Nghiên cứu ảnh hương của Phật giáo đối với nguời Việt hiện nay", của Nguyễn Thị Thơm - Học viện Phật giáo Việt Nam.

- “Tín nguõ̃ng và văn hóa tín nguõng ở Việt Nam” của Ngô Đức Thịnh, NXB trẻ.

Thứ tư, một số luận văn, luận án có liên quan đến đời sống người dân trong thời kỳ nông thôn mới, tiêu biểu như: 
- Luận văn "Hệ muc tiêu của chủ nghĩa xã hội ở Việt Nam trong thời kỳ đổi mới" của Phạm Văn Hùng, trường Đại học Khoa học xã hội và Nhân văn, Đại học Quốc gia Hà Nội.

- Luận văn "Chuyển biến kinh tế xã hội ở huyện Sơn Dưong (tỉnh Tuyên Quang) trong đời kỳ đổi mới, (giai đoạn 1986-2010), của Nguyễn Thị Thu Trang, trường Đại học Sư phạm.

- Luận văn "Công nghiệp hóa, hiện đại hóa nông nghiệp nông thôn ở Việt Nam" của Nguyễn Văn Dũng, trường Đại học kinh tế, Đại học Quốc gia Hà Nội.

Ngoài ra còn có nhiều bài viết về đời sống văn hóa, tôn giáo, tín ngưỡng ở nông thôn Việt Nam xưa và nay đăng trên các báo, tạp chí, báo điện tử.

Các công trình nói trên đã dựng nên bức tranh chung về điều kiện địa lý, tự nhiên, môi trường kinh tế, văn hóa, trình bày những quan điểm, chính sách của Đảng và Nhà nước đối với quá trình phát triển nông thôn Việt Nam, đặc biệt là vấn đề bảo tồn, phát huy những giá trị văn hóa của nông thôn Việt Nam. Văn hóa truyền thống trong làng xã Việt Nam được trình bày trong sự vận động biến đổi của các giá trị văn hóa vật thể và phi vật thể. Vấn đề bảo tồn, giữ gìn các giá trị truyền thống văn hóa cũng được nhìn nhận từ góc độ phát triển, trong sự nghiệp phát triển chung của đất nước. Có thể nói, đây là những nghiên cứu có tính khái quát nhất có liên quan đến đời sống văn hóa nông thôn Việt Nam.

Những công trình nghiên cứu trên không những có thái độ trân trọng đối với truyền thống văn hóa mà còn tổng kết, kế thừa những thành tựu nghiên cứu khoa học trong nước về văn hóa làng xã, tiếp tục nghiên cứu, trình bày một cách có hệ thống những đặc điểm của văn hóa và đời sống của người dân sống ở vùng nông thôn Việt Nam từ truyền thống đến hiện đại. Một số công trình đã bàn đến những vấn đề đặt ra trong việc xây dựng đời sống nông thôn hiện nay ở một số vùng cụ thể. 
Điều đáng lưu ý, phần lớn những kết quả nghiên cứu trên đây gắn với sự phát triển chung của sự nghiệp đổi mới đất nước. Những thành tựu nghiên cứu đã có hệ thống, khái quát những nét cơ bản quá trình vận động phát triển văn hóa vùng nông thôn. Tuy nhiên đến nay chưa có một công trình nào nghiên cứu về nhà văn hóa trong đời sống nông thôn Việt Nam. Đề tài nghiên cứu của tôi sẽ tiếp tục bổ sung những thành quả nghiên cứu trên đây. Các công trình nghiên cứu đó sẽ là những gợi mở quan trọng cả về lý luận và thực tiễn để tôi tiến hành nghiên cứu vấn đề "Nhà văn hóa trong đời sống nông thôn hiện nay - qua việc nghiên cứu, khảo sát các hoạt động của nhà văn hóa Hương Xạ - xã Hương Xạ - huyện Hạ Hòa - tỉnh Phú Thọ”

\section{3. Đối tượng nghiên cứu}

Khóa luận nghiên cứu tổng thể không gian sinh hoạt và các hoạt động diễn ra tại ngôi nhà văn hóa Hương Xạ thuộc xã Hương Xạ, huyện Hạ Hòa, tỉnh Phú Thọ. Về thời gian: khảo sát, phân tích thực trạng không gian sinh hoạt và các hoạt động diễn ra tại nhà văn hóa Hương Xạ từ năm 2006 đến nay; về không gian: Nhà văn hóa Hương Xạ.

\section{Mục đích nghiên cứu}

Đề tài nghiên cứu về nhà văn hóa trong đời sống nông thôn làng Hương Xạ - xã Hương Xạ - huyện Hạ Hòa - tỉnh Phú Thọ sẽ chỉ ra được hiện trạng của nhà văn hóa trong đời sống nông thôn. Từ đó đưa ra nhận xét về tình trạng và kết luận về những điểm mạnh, điểm hạn chế trong việc khai thác và sử dụng nhà văn hóa. Và cuối cùng là đưa ra giải pháp: Làm sao để nâng cao hiệu quả sử dụng nhà văn hóa trong đời sống nông thôn Việt Nam?

Nhiệm vụ

Để đạt được mục đích trên, khóa luận có nhiệm vụ:

- Trình bày nét khái quát tình hình chung của làng Hương Xạ từ vị trí địa lý, điều kiện tự nhiên đến đời sống văn hóa, kinh tế, lịch sử, xã hội,...của người dân qua các thời kỳ lịch sử. 
- Trình bày những chủ trương của Đảng và Nhà nước về việc xây dựng nhà văn hóa khu dân cư, từ đó nhấn mạnh việc triển khai xây dựng nhà văn hóa Hương Xạ.

- Khảo sát, mô tả, đánh giá thực trạng của nhà văn hóa Hương Xạ, tính từ thời gian xây dựng đến nay. Đề xuất giải pháp nhằm nâng cao hiệu quả sử dụng nhà văn hóa.

\section{Phương pháp nghiên cứu}

Đề tài thực hiện dựa trên cơ sở nghiên cứu đường lối, chủ trương, chính sách phát triển văn hóa của Đảng và Nhà nước ta. Chính vì thế, các phương pháp nghiên cứu chủ yếu được sử dụng là: phương pháp thống kê, phương pháp lô gic và lịch sử, phương pháp phân tích tài liệu, phương pháp tổng hợp, phương pháp điều tra thực tế, phương pháp phỏng vấn.

Phương pháp thống kê, phương pháp logic và lịch sử giúp nghiên cứu các yếu tố hình thành làng Hương Xạ.

Phương pháp điều tra thực tế, phỏng vấn sâu giúp thu thập những số liệu quan trọng để mô tả hiện trạng đang diễn ra tại nhà văn hóa Hương Xạ.

Phương pháp tổng hợp, phân tích tài liệu có một vị trí quan trọng, liên quan trực tiếp đến đề tài. Phương pháp tổng hợp, phân tích tài liệu giúp đưa ra những nhận định chung nhất về nhà văn hóa Hương Xạ.

\section{Cấu trúc đề tài}

Không kể phần mở đầu, phần kết luận, danh mục tài liệu tham khảo, nội dung của khóa luận được trình bày trong 3 chương như sau:

Chương 1. Tổng quan làng Hương Xạ, xã Hương Xạ - huyện Hạ Hòa tỉnh Phú Thọ

Chương 2. Nhà văn hoá Hương Xạ - huyện Hạ Hoà - tỉnh Phú Thọ

Chương 3: Hoạt động của Nhà văn hoá Hương Xạ và những vấn đề đặt ra 


\section{NỘI DUNG}

\section{Chương 1. TỔNG QUAN LÀNG HƯƠNG XẠ, XÃ HƯƠNG XẠ - HUYỆN HẠ HÒA - TỈNH PHÚ THỌ}

\subsection{Vị trí địa lý, điều kiện tự nhiên và môi trường sinh thái}

\subsubsection{Vị trí địa lý}

Hương Xạ là một xã miền núi thuộc huyện Hạ Hoà - tỉnh Phú Thọ, xã Hương Xạ có diện tích là 14.528 ha với tổng dân số là 6.814 nhân khẩu (năm 2014), được phân bố đều trên 13 khu hành chính.

Hương Xạ có vị trí toạ độ từ $21^{\circ} 33^{\prime}$ đến $21^{\circ} 52^{\prime}$ vĩ độ Bắc và $105^{\circ} 04^{\prime}$ đến $105^{\circ} 2^{\prime}$ kinh độ Đông. Phía Bắc Hương Xạ giáp với xã Phương Viên, phía tây giáp với xã Âm Hạ, phía đông giáp với xã Cáo Điền, xã Yên Kỳ; phía nam giáp với xã Chính Công (các xã Phương Viên, Âm Hạ, Cáo Điền, Yên Kỳ, Chính Công đều thuộc địa phận huyện Hạ Hoà - tỉnh Phú Thọ).

Hương Xạ là một xã nhỏ thuộc địa phận huyện Hạ Hoà, tỉnh Phú Thọ. Xã có mạng lưới giao thông đơn giản, $100 \%$ là đường bộ, tiêu biểu và quan trọng nhất là đoạn đường bộ dài hơn $10 \mathrm{~km}$ chạy dọc theo Quốc lộ 32. Quốc lộ 32 là tuyến đường kéo dài từ Hà Nội qua Phú Thọ đến Yên Bái và kết thúc ở Tam Đường - Lai Châu, khoảng cách từ xã Hương Xạ đến thị trấn Hạ Hoà nếu đi dọc theo tuyến đường này mất khoảng $12 \mathrm{~km}$, khoảng cách từ xã Hương Xạ đến thành phố Việt Trì (vị trí trung tâm của tỉnh) mất khoảng $65 \mathrm{~km}$. Các tuyếnđường còn lại chạy qua xã chủ yếu là các con đường bê tông hoá, ngắn và dốc nên chỉ có thể cho phép các phương tiện thô sơ đi lại, chính vì thế phần lớn người dân đi lại và trao đổi buôn bán tại địa phương, ít mở rộng ra bên ngoài.

Về mặt địa hình, địa hình xã Hương Xạ thuộc dạng lòng chảo, thoải dần theo hướng Đông Nam, địa hình xã Hương Xạ được tạo bởi các triền núi cao, tiêu biểu nhất là núi Buộm (khu 2. - xã Hương Xạ). 


\subsection{2. Điều kiện tự nhiên}

Xã Hương Xạ nằm trong vùng khí hậu nhiệt đới ẩm gió mùa và mang nhiều nét đặc trưng của khí hậu miền Tây Bắc. Nhiệt độ trong năm trung bình từ $22-24^{\circ} \mathrm{C}$, cao nhất vào tháng $5-6$, khoảng $33-34^{\circ} \mathrm{C}$, có lúc lên tới $41^{\circ} \mathrm{C}$ và thấp nhất vào tháng 1 , khoảng $12-13^{\circ} \mathrm{C}$, có lúc xuống tới $4^{0} \mathrm{C}$. Lượng mưa trung bình trong địa bàn xã khoảng $2.000 \mathrm{~mm}$. Mùa mưa kéo dài từ tháng 5 đến tháng 10 , chiếm $80-85 \%$ lượng mưa cả năm (cao điểm vào các tháng $6,7,8)$; mùa khô kéo dài từ tháng 11 đến tháng 12 , chiếm 15-20\% lượng mưa cả năm, độ ẩm trung bình khoảng $80-85 \% / n a ̆ m$, trong đó độ ẩm cao nhất khoảng $95 \%$, thấp nhất khoảng $60 \%$.

Tại Hương Xạ còn có nhiều loại gió, gió mùa đông bắc kéo dài từ tháng 12 đến tháng 3 , tạo nên sự mát mẻ và mưa nhiều; gió đông bắc xen kẽ gió đông nam, mỗi đợt kéo dài vài ba ngày, khiến cho khí hậu khô nóng, độ ẩm thấp. Có thời điểm còn xuất hiện sương muối trên địa bàn xã. Những năm gần đây, trên địa bàn xã Hương Xạ còn thường xuyên xuất hiện bão lốc cục bộ kèm theo mưa đá vào các tháng $4,5,6$ hàng năm.

\subsubsection{Môi trường sinh thái}

Xã Hương Xạ là nơi có hệ thống hồ, đầm, ao, suối khá phong phú với trữ lượng nước lớn được người dân dùng trong việc cung cấp nước sinh hoạt, sản xuất, nuôi trồng, chăn nuôi gia súc, gia cầm. Tuy nhiên, do tốc độ dòng chảy lớn trong mùa mưa và luôn thay đổi nên vùng đất ven sông, hồ thuộc xã Hương Xạ thường xuyên xảy ra xói lở, úng lụt, điều đó gây không ít trở ngại cho sản xuất và sinh hoạt.

Tài nguyên khoáng sản của Hương Xạ nghèo nàn, chủ yếu là đất, đá được khai thác để sản xuất các vật liệu xây dựng như: gạch, ngói, xi măng,...

Về thổ nhưỡng, Hương Xạ có một số loại đất như: đất ferarit đỏ vàng, đất phù sa xen lẫn đất đồi núi, đất lầy thụt, đất dốc tụ, đất bạc màu, đất chiêm trũng úng nước trong mùa mưa. 
Về tài nguyên rừng, Hương Xạ là vùng đất giàu có về tài nguyên rừng. Những dải rừng gỗ lim xanh, tràm trắng, chò nâu, dẻ gai, dẻ đá hoặc kém hơn như: mỡ, hu, ba soi, chẹo,...hay những cánh rừng tre, nứa xen cây hoặc rừng tre nứa thuần khiết thường được trồng rất nhiều ở những khu vực xa đường giao thông, đi lại khó khăn. Tuy nhiên, cho đến nay các cây gỗ quý ở xã Hương Xạ còn lại rất ít, chỉ còn vài cây sồi, rẻ, re,... nằm dải rác trong những rừng cây keo, bạch đàn.

Chính dạng địa hình trên đã tạo ra các vùng sinh thái khác nhau cho xã như: vùng đồi thấp, vùng đồi cao, vùng núi; điều kiện khí hậu và môi trường tự nhiên khác biệt đã tạo điều kiện thuận lợi để xã Hương Xạ phát triển toàn diện cả về nông, lâm nghiệp.

\section{2. Quá trình hình thành và phát triểncủa làng Hương $X a ̣$}

\subsubsection{Lịch sử hình thành và sụ thay đổi đơn vị hành chính làng Hương Xạ.}

Theo "Đại Nam nhất thống chí" vào thời Hùng Vương, vùng đất Hương Xạ ngày nay thuộc đất Phong Châu, trung tâm của nước Văn Lang. Trong thời Bắc thuộc vùng đất này thuộc các huyện Tân Hưng (đời Ngô), quận Tân Xương (đời Tấn, Tống, Tề), Hưng Châu (đời Trần) và Châu Phong (đời Tùy), thuộc quận Giao Chỉ. Đến thời Đường nó thuộc phủ Phong Châu, đạo Lĩnh Nam. Vào thời kỳ độc lập, dưới các triều đại Đinh (968-980), Tiền Lê (9801009), Lý (1009-1225), vùng đất nay là xã Hương Xạ thuộc lộ Lâm Thao. Đến thời Lê, theo Hồng Đức bản đồ vùng đất này thuộc huyện Hạ Hòa phủ Thao Giang thuộc thừa tuyên Sơn Tây. Từ năm Hồng Đức thứ 21 năm 1490, thừa tuyên Sơn Tây được đổi làm trấn Sơn Tây, huyện Hạ Hoa thuộc phủ Lâm Thao trấn Sơn Tây. Thời Nguyễn, năm Minh Mạng thứ 12 (1831), cải cách hành chính của Minh Mạng đã đổi trấn Sơn Tây thành tỉnh Sơn Tây, Huyện Hạ Hoa được đổi thành huyện Hạ Hòa, phủ Lâm Thao. Từ năm 1893, Hương Xạ thuộc tổng Yên Kỳ, huyện Hạ Hòa, phủ Lâm Thao, tỉnh Hưng Hóa. 
Sau cách mạng tháng 8 năm 1945, nhà nước Việt Nam thống nhất gọi các phủ, châu, huyện là huyện, bỏ cấp tổng và tiến hành hợp nhất các làng nhỏ thành xã, lúc này làng Hương Xạ thuộc địa phận xã Phú Ích, huyện Thanh Hoà, tỉnh Vĩnh Phú. Đến năm 1969, nhà nước lại tiến hành chia tách và đổi tên các đơn vị hành chính trong các tỉnh thành, lúc này làng Hương Xạ thuộc địa phận xã Hương Xạ, huyện Hạ Hoà, tỉnh Phú Thọ, sự thay đổi đó tồn tại đến tận bây giờ.

Hiện nay, chưa có tài liệu ghi lại làng Hương Xạ được thành lập chính thức vào thời gian nào, tuy nhiên theo lời kể của các cụ già trong làng: xa xưa vùng đất Hương $X a$ còn là vùng đất trống chưa có người ở, vào cuối thời nhà Lê, cách ngày nay khoảng 300 năm, có một người tên là Tống Văn Vụ đứng ra đại diện cho bốn dòng họ: Tống, Bùi, Phùng, Nguyễn, là người vùng Thái Bình đã viết đơn xin đến đây khai hoang lập làng. Mảnh đất mà họ đã khai khẩn lấy tên làng là Hương Xạ, làng thuộc xã Hương Xạ, tổng Yên Kỳ huyện Hạ Hòa.

Dưới thời Nguyễn, vào cuối thế kỷ 19, cụ Bùi Văn Khai (giữ chức Phó tổng Yên Kỳ), đứng ra quản lý làng Hương Xạ, cụ Bùi Văn Khai được triều đình phong kiến nhà Nguyễn phong chức Bá hộ quản lý làng, và người dân làng Hương Xạ thường gọi cụ là cụ Bá. Cụ Bá là một nhà nho yêu nước, cụ đã từng giúp đỡ đề Ngân, đề Mạc chống Pháp nhưng thất bại. Trong cuộc vận động cách mạng giải phóng dân tộc dưới sự lãnh đạo của Đảng cộng sản Đông Dương cụ đã vận động gia đình và người dân trong làng tích cực giúp đỡ cách mạng.

\subsubsection{Làng Hương Xạ trong các giai đoạn lịch sử}

\subsubsection{Làng Hương Xạ tù̀ khi thành lập đến năm 1945}

\section{Tình hình kinh tế}

Tình hình kinh tế làng Hương Xạ xưa kia khá đơn sơ và nhỏ lẻ, do đây là một vùng đất thưa dân, trình độ dân trí thấp và chủ yếu là dân từ các vùng khác đến đây lập nghiệp. Ngày đó, người dân sống chủ yếu nhờ nghề trồng 
lúa và lên rừng hái măng, hái nấm, đào củ mài, lấy cây nứa, cây tre, ngọn chít,...về sử dụng hoặc bán lấy tiền sống cho qua ngày.

Về nông nghiệp: Đại bộ phận người dân trong làng đều làm nghề nông trồng lúa nước, mỗi năm họ cấy hai vụ (một vụ mùa và một vụ chiêm). Mặc dù làng Hương Xạ nằm ở vùng trung du miền núi Bắc Bộ nhưng ở đây không có ruộng bậc thang mà chủ yếu là các ruộng nước trũng (người dân nơi đây gọi là ruộng rộc), nằm ở ven các quả đồi và ven các con suối. Tổng diện tích của tất cả các thửa ruộng của người dân trong làng khoảng 700 - 800ha. Ngoài cấy lúa, người dân Hương Xạ còn trồng các loại cây hoa màu như: ngô, khoai, sắn,...trên các bãi đất nhỏ ven chân đồi, nơi giáp ranh giữa ruộng và đồi.

Về lâm nghiệp: Diện tích đất lâm nghiệp ở làng Hương Xạ khá lớn, khoảng 1000 ha, đó là những cánh rừng nguyên sơ, rừng đầu nguồn có nhiều loại gỗ quý như: gỗ lim xanh, tràm trắng, chò nâu, dẻ gai, dẻ đá hoặc kém hơn như: mỡ, hu, ba soi, chẹo,... Tuy nhiên, ngày đó những cánh rừng này chủ yếu do triều đình đứng ra quản lý nên người dân cũng không khai thác được nhiều. Những thửa rừng nhỏ mà người dân được triều đình giao làm thời vụ thì được trồng: các loại cây lấy gỗ (sồi, bồ đề,...), đặc biệt là trồng chè và cọ.

Về chăn nuôi: mỗi hộ gia đình thường nuôi 1-2 con trâu hoặc bò, 1-2 con lợn, 1-2 con chó, vài ba chục con gà, con vịt,...để lấy sức kéo và thức ăn cải thiện cuộc sống.

Về chơ và các hoạt động thuơng nghiệp: Vì nghề nghiệp chính của người dân làng Hương $X a$ chủ yếu là nông nghiệp và khai thác các tài nguyên có sẵn trên rừng cho nên các mặt hàng buôn bán ở đây phổ biến là các loại nông, lâm sản như: gạo, măng, nứa, tre,...ngoài ra còn có chè và các loại gia súc, gia cầm như: trâu, bò, lợn, ngan, gà, vịt,... Việc buôn bán ở đây diễn ra khá đều đặn, vì thế cũng có một vài nhà buôn từ các xã, huyện lân cận đến buôn bán như: huyện Thanh $\mathrm{Ba}$, huyện Đoan Hùng,... Hệ thống chợ ở đây không nhiều, chỉ có một chợ duy nhất được xây dựng gần tuyến đường Quốc lộ 32 , chợ họp chủ yếu vào sáng thứ 7 hàng tuần. 
Ngoài nền kinh tế nông nghiệp và lâm nghiệp thì ở đây cũng có một cơ sở sản xuất chế biến gỗ, một cơ sở chế biến chè,... thu hứt mấy chục nhân công lao động trong làng.

Bộ máy quản lý làng Huơng Xạ: Xa xưa, làng Hương Xạ là một ngôi làng thuộc xã Hương Xạ, Tổng Yên Kỳ - huyện Hạ Hoà - tỉnh Phú Thọ. Làng Hương Xạ do cụ Bùi Văn Khai - giữ chức Phó tổng Yên Kỳ, đứng ra quản lý. Ngày đó, ông Bùi Văn Khai vừa là người quản lý làng, vừa là người tiếp nhận, phổ biến những mệnh lệnh, yêu cầu của cấp trên đến người dân trong làng, công việc quan trọng nhất của ông tại làng là đảm nhiệm việc thu thuế.

Sau một thời gian, các quan viên trong làng Hương Xạ bầu ra Hội đồng Kỳ mục - Hội đồng kỳ mục đã nhanh chóng trở thành một bộ phận quan trọng trong bộ máy quản lý làng Hương Xạ với sự có mặt của cựu chánh phó tổng, chức sắc cùng quan lại về hưu, các cựu lý phó trưởng,...đứng đầu là Bùi Văn Lai giữ chức tiên chỉ và Nguyễn Văn Bá giữ chức phó tiên chỉ. Bùi Văn Lai và Nguyễn Văn Bá được toàn quyền quyết định công việc trong làng như: phân bổ thuế khoá, sưu dịch, binh tráng, bầu cử tổng lý, phân cấp công điền, xây dựng và tu bổ đình, chùa, tổ chức hội hè, đình, đám.

Làng Hương Xạ xưa còn được quản lý bằng hương ước, hương ước đã được ghi thành văn bản với nội dung khá toàn diện, đề cập đến các vấn đề như: kinh tế, bảo vệ môi trường, ngôi thứ, hương ẩm,.. an ninh, hôn nhân... Hương ước có vai trò vô cùng quan trọng trong việc ổn định trật tự làng, giải quyết tốt đời sống tâm linh, góp phần làm phong phú đời sống cộng đồng. Cũng giống như nhiều vùng nông thôn khác trong khu vực, xưa kia làng Hương Xạ cũng tổ chức tập hợp người dân theo nghề nghiệp (gọi là phường như: phường chè, phường mộc), theo trình độ học vấn (gọi là hội tư văn, hội tư võ). Về mặt xã hội, làng Hương Xạ còn phân thứ bậc khác nhau phụ thuộc vào phẩm hàm, bằng cấp, chức tước, tài sản với những nghĩa vụ và quyền lợi khác nhau. 
Tình hình văn hóa, tôn giáo, tín ngưỡng: Từ xa xưa người dân làng Hương Xạ đã coi trọng vấn đề văn hoá, văn hoá không chỉ giúp người dân làng Hương Xạ duy trì sự phát triển bền vững mà còn giúp giữ gìn trật tự an sinh xã hội.

Ngay từ khi làng mới ra đời người dân trong làng đã xây dựng đình làng. Đình làng đã nhanh chóng trở thành không gian sinh hoạt cộng đồng quan trọng giúp gắn bó người dân trong làng Hương Xạ với nhau, đình làng sẽ là ngôi nhà chung chứng kiến những hoạt động, những lề thói của dân làng Hương Xạ. Vì thế, thời gian trước năm 1945, đình làng là không gian sinh hoạt văn hóa của người dân nơi đây.

Ngay từ mới được xây dựng, ngôi đình làng Hương Xạ đã có chức năng như ngôi nhà lớn của cộng đồng: Đây là nơi để nhân dân hội họp, nộp sưu thuế, nơi thờ thành Hoàng làng. Ngày đó, đình làng chính là một biểu tượng quyền lực ở làng Hương Xạ. Tuy nhiên, trước sự tàn phá của chiến tranh, ngôi đình làng Hương Xạ chỉ còn là phế tích.

Về phong tục tập quán, ăn trầu là tục được nhắc đến sớm nhất trong lịch sử làng Hương Xạ. Thời xưa, người dân làng Hương Xạ ai ai cũng ăn trầu, dần dần, tục ăn trầu trở thành biểu tượng của tình đoàn kết, tình anh em, tình vợ chồng.

Trong cưới xin, xưa kia người dân làng Hương Xạ tổ chức lễ cưới vào buổi tối. Trong hôn lễ, người Hương Xạ quy định có sáu lễ chính, đó là: Lễ nạp thái, lễ vấn danh, lễ nạp cát, lễ nạp tệ, lễ thỉnh kỳ, lễ thân nghinh. Lễ nạp thái là lễ sau khi nghị hôn, nhà trai mang sang nhà gái một cặp "nhạn" để tỏ ý đã kén chọn ở nơi ấy. Lễ vấn danh là lễ do nhà trai sai người làm mối đến hỏi tên tuổi và ngày sinh tháng đẻ của người con gái. Lễ nạp cát là lễ báo cho nhà gái biết rằng đã xem bói được quẻ tốt, nam nữ hợp tuổi nhau thì lấy được nhau. Lễ nạp tệ (hay nạp trưng) là lễ nạp đồ sính lễ cho nhà gái, minh chứng cho sự hứa hôn chắc chắn của hai bên gia đình. Lễ thỉnh kỳ: là lễ xin định ngày giờ làm rước dâu tức lễ cưới. Và sau cùng là lễ thân nghinh (tức lễ rước 
dâu hay lễ cưới), lễ này được cử hành vào đúng ngày giờ đã định, họ nhà trai mang lễ đến nhà gái để rước dâu về.

Trong lễ tang, trang phục trong đám tang của người dân làng Hương Xạ được quy định rõ: Con trai phải đội mũ rơm quấn bẹ chuối, áo sô gai, cầm gậy (cha mất thì gậy tre, mẹ mất thì gậy vông); con dâu, con gái phải mặc áo sô gai, thắt lưng bện bằng bẹ chuối, áo xổ gấu hoặc không (tùy theo cha còn hay mẹ còn, con gái còn ở nhà hay đã xuất giá), đầu chít khăn tang; cháu nội phải đội mũ mấn, khăn trắng, mặc áo thụng trắng; con rể, anh em trai phải mặc áo thụng trắng; chị em gái phải quấn vặn khăn trắng với tóc.

Về lễ nghi, trong một năm người dân làng Hương Xạ tổ chức rất nhiều ngày lễ, ngày Tết như: Tết Nguyên Đán, Tết Nguyên tiêu, Tết Hàn thực, Tết Đoan ngọ, Tết Trung thu,...

Về trang phục, trong thời phong kiến, người dân làng Hương Xạ có những quy định rất khắt khe về cách ăn mặc, dân thường chỉ được mặc những bộ quần áo bà ba màu đen, nâu hoặc trắng. Quần áo của người dân hầu hết là tầm thường và đơn sơ để hợp với thân phận của mình trong xã hội.

Về tín ngưỡng, người dân làng Hương Xạ có rất nhiều tín ngưỡng nhu: tín ngưỡng thờ Thành hoàng làng, tín ngưỡng thờ cúng tổ tiên, thờ danh nhân và anh hùng (Vua Hùng, mẹ Âu Cơ,..); tín ngưỡng sùng bái thần linh (thổ địa, thần tài, táo quân),...

Về tôn giáo, mặc dù người dân làng Hương Xạ không theo tôn giáo nào nhưng họ có lòng tin vào Phật giáo. Chính vì thế, ngay từ khi lập làng họ đã cùng nhau xây dựng một ngôi chùa lấy tên là chùa Hương Sơn. Chùa Hương Sơn được xây dựng cách ngày nay khoảng 300 năm cùng với sự hình thành ngôi làng Hương Xạ. Theo lời kể của bác Bùi Văn Tạo, (bác hiện là Đại tá về hưu) cho biết: "Hưong Xạ là một vùng đất rộng nhung địa hình chủ yếu là rùng núi nên việc đii lại rất khó khăn, thời loạn lạc cu dân tù nơi khác chuyển đến định cu ngày một đông, lúc đó ngườ dân làng Huơng Xạ đã cùng nhau xây dụng một ngôi chùa để phục vụ cho mục đích tôn giáo, đó là chùa Huơng 
Son. Chùa Hương Son được làm bằng gỗ theo kết cấu chũ đinh gồm: ba gian tiền đường, một gian hậu cung lợp ngói, bên trong có tương phật Thích Ca làm bằng gỗ.Trước cách mạng tháng 8 năm 1945, chùa là noi hội họp bí mật của các tổ chức cách mạng, còn trong kháng chiến chống Pháp, chùa là nơi hội họp của các đoàn thể nhân dân làng Huơng Xạ. Năm 1957, chùa Hương Son bi sụp đổ hoàn toàn, chỉ còn lại nền, đá kê".

\subsubsection{Hương Xạ tù̀ 1945 đến 1954.}

Cách mạng Tháng 8 năm 1945 đã lật đổ ách thống trị của chế độ thực dân phong kiến, thiết lập nên Nhà nước Việt Nam Dân chủ Cộng hoà, mở ra một kỷ nguyên mới trong lịch sử của dân tộc Việt Nam: kỷ nguyên Độc lập Tự do. Sau khi ra đời, chính quyền cách mạng non trẻ nước ta đã phải đối phó với một tình thế hết sức hiểm nghèo, hàng loạt thách thức tưởng chừng khó có thể vượt qua, đó là "giặc đói", "giặc dốt", và đặc biệt là "giặc ngoại xâm”. Trong tình hình đó, Đảng ta và Chủ tịch Hồ Chí Minh đã có những quyết sách đúng đắn, sáng suốt để vượt qua khó khăn, kịp thời ứng phó với những thách thức đe dọa sự tồn vong của chính quyền cách mạng non trẻ, xây dựng chế độ mới, đưa cách mạng đi lên.

Trong bối cảnh đó, ngày 6 tháng 9 năm 1945 tại làng Hương Xạ, anh Triệu Văn Điều đã cùng một số anh em con cháu họ Bùi đứng ra tuyên bố giải tán Hội đồng kỳ mục, thành lập chính quyền lâm thời. Lúc đó, ông Tống Văn Vịnh được bầu làm Chủ tịch lâm thời, bà Tống Thị Quýnh và ông Nguyễn Văn Hiệp được bầu làm Phó Chủ tịch lâm thời; ông Bùi Xuân Sáng và ông Cù Văn Lều phụ trách lực lượng vũ trang bảo vệ cách mạng.

Năm 1946, sau cuộc tổng tuyển cử bầu ra Quốc hội và Hội đồng nhân dân các cấp đầu tiên diễn ra ở Việt Nam, tại làng Hương Xạ Hội đồng nhân dân xã đã bầu Bùi Văn Thai làm Chủ tịch Uỷ ban Liên khu Kháng chiến Hành chính, gồm 6 làng: Hương Xạ, Yên Kỳ, Chính Công, Phương Viên, Cáo Điền, Đàn Trầm. 
Từ năm 1945 đến năm 1947, làng Hương Xạ liên tục đón các cơ quan Trung ương về sơ tán, làng Hương Xạ là nơi nuôi dưỡng, giúp đỡ tiểu đoàn pháo binh Voi Gầm (Voi Gầm là tên gọi của ông Doãn Tuế - là người giữ chức Tư lệnh bộ đội pháo binh Việt Nam).

Trong thời kỳ kháng chiến chống Pháp, làng Hương Xạ là nơi đóng quân của Trung đoàn 209 - Sư đoàn 312, là nơi trạm quân y 6 - quân y 4 phụ trách chữa trị cho thương binh tham gia chiến dịch sông Lô năm 1949, là nơi làm việc của Uỷ ban kháng chiến Liên khu 10 - Việt Bắc, là nơi tổ chức Đại hội Đảng lần thứ 2 của tỉnh Phú Thọ và đặc biệt làng Hương Xạ là nơi đóng quân của tiểu đoàn an dưỡng 312 - sư đoàn 316. Trong cuộc kháng chiến chống thực dân Pháp, nhân dân làng Hương Xạ luôn tích cực đóng góp lúa, gạo nuôi quân, ngoài ra người dân còn làm bánh chưng, bánh dày gửi ra các mặt trận nuôi bộ đội.

Năm 1950, làng Hương Xạ được sáp nhập vào địa phận xã Phú Ích, lúc đó xã Phú Ích gồm có bốn làng: Hương Xạ, Cáo Điền, Phương Viên và Đàn Trầm.

\subsubsection{Hương Xạ tù̀ 1955 đến1986}

Sau cải cách ruộng đất, làng Hương Xạ đã xoá bỏ vĩnh viễn chế độ người bóc lột người, uy thế chính trị, kinh tế của địa chủ bị triệt tiêu, địa vị chính trị của giai cấp nông dân được xác lập.

Tháng 5 năm 1956, Nhà nước đưa ra chủ trương "Bảo đảm quyền sở hữu ruộng đất" [thuvienphapluat.vn] và khuyến khích người dân khai hoang mở rộng diện tích gieo trồng, đồng thời đẩy mạnh phong trào "xây dựng tổ đổi công giúp đỡ nhau trong sản xuất", hình thức này đã nhanh chóng phát triển rộng khắp trên địa bàn làng Hương Xạ.

Cuối năm 1959, hoà theo chương trình xây dựng hợp tác xã doTrung ương đề ra, làng Hương $X a ̣$ đã thống nhất xây dựng hợp tác xã Nông nghiệp Hương Xạ. Ngay sau khi thành lập, hợp tác xã đã thu hút được 50 hộ nông dân trong làng, chiếm tỷ lệ $85 \%$.Với phong trào làm ăn tập thể, hợp tác xã 
nông nghiệp Hương Xạ đã có điều kiện khai khẩn thêm nhiều mảnh đất bỏ hoang trên địa bàn.

Phấn khởi trước những kết quả đạt được trong thời kỳ khôi phục kinh tế, người dân làng Hương Xạ đã hăng hái thi đua lao động sản xuất, xây dựng hợp tác xã. Các chiến dịch khai hoang phục hoá, mở rộng diện tích canh tác, làm thuỷ lợi tiêu úng, làm phân bón cải tạo đất chua, chống lầy thụt, chống xói mòn bảo vệ đất, cải tiến công cụ,...đã tạo nên hiệu quả rõ rệt.

Năm 1980-1981, làng Hương Xạ chịu ảnh hưởng thường xuyên của lũ lụt, hạn hán nên đời sống nhân dân sa sút do mất mùa. Cuộc sống của người dân vất vả, đói kém đã dẫn đến tình trạng: xã viên không đủ sức khoẻ làm việc, họ đi làm chỉ để tính số lượng ngày công vì thế chất lượng làm việc ngày càng thấp, trong khi đó các chính sách ở tầm vĩ mô thì chưa phù hợp đã ảnh hưởng không nhỏ tới tư tưởng người dân trong làng.

Giữa lúc sản xuất nông nghiệp trong xã đang bị trì trệ, đời sống nhân dân khó khăn thì ngày 13-1-1981, Ban Bí thư Trung ương ra chỉ thị 100$\mathrm{CT} / \mathrm{TW}$ về cải tiến công tác khoán trong nông nghiệp. Sau hơn một năm triển khai khoán 100 trên lĩnh vực sản xuất nông nghiệp, làng Hương Xạ đạt được một số kết quả nhất định trong việc mở rộng được nhiều ngành nghề: chăn nuôi, sản xuất vật liệu xây dựng, chế biến hàng nông sản, chuyên canh khai thác cây cọ, cây chè, hệ thống thuỷ lợi và các dịch vụ buôn bán nhỏ lẻ khác luôn được cải tiến.

Đến năm 1985, nền kinh tế của làng Hương Xạ vẫn còn gặp không ít khó khăn: năng suất lúa thấp, bình quân lương thực đầu người giảm, hợp tác xã với mô hình cũ ngày càng bộc lộ những hạn chế, nhất là tình trạng khoán trắng, buông trôi, nợ đọng của xã viên đối với hợp tác xã ngày càng tăng. Như vậy, sau một thời gian thực hiện, chủ trương "khoán 100" chưa thực sự là đòn bẩy kích thích nền kinh tế phát triển.

Trong thời kỳ bao cấp người dân làng Hương Xạ chủ yếu làm việc ở hợp tác xã: họ làm việc, ăn uống chung với nhau tại trụ sở hợp tác xã, chính vì thế 
họ đã tạo dựng lên một không gian sinh hoạt văn hóa riêng cho mình ngay tại hội trường hợp tác xã. Có những gia đình tổ chức đám cưới luôn ở hội trường hợp tác xã để tận dụng bàn ghế, bát đĩa,... có trong nhà kho hợp tác xã, những buổi chiếu bóng cho người dân cũng được tổ chức ở sân trụ sở hợp tác xã,... Từ đó hợp tác xã nông nghiệp Hương Xạ như một ngôi nhà chung của nhiều thế hệ, nó gắn liền với cuộc sống văn hóa người dân làng Hương Xạ.

Về tôn giáo, tín ngưỡng: Trong thời gian này, chùa Hương Sơn vẫn chưa được xây dựng lại do điều kiện kinh tế của người dân còn khó khăn. Từ trước năm 1945, tín ngướng thờ Thành hoàng làng không còn tồn tại cùng với sự sụp đổ của đình làng.

\subsubsection{Hương Xạ tù̀ 1986 đến nay}

Trong ba năm 1986-1988, Hương Xạ gặp không ít khó khăn do thời tiết khắc nghiệt, vật tư nông nghiệp cung cấp cho sản xuất vừa thiếu lại không kịp thời, giá cả luôn luôn biến động đã chi phối nhiều đến tình hình sản xuất và đời sống người dân.

Năm 1988, thực hiện Nghị quyết khoán 10, Hương Xạ đã giao quyền sử dụng ruộng đất cho người lao động và xác định rõ hộ gia đình là đơn vị nhận khoán. Trong Nghị quyết khoán 10 năm 1988 nêu rõ:

"Nhà nước công nhận sự tồn tại lâu dài và tác dụng tích cực của kinh tế cá thể, tư nhân trong quá trình đi lên chủ nghĩa xã hội; thừa nhận tư cách pháp nhân, bảo đảm bình đẳng về quyền lợi và nghĩa vụ trước pháp luật, bảo hộ quyền làm ăn chính đáng và thu nhập hợp pháp của các hộ cá thể, tư nhân và quyền thừa kế sử dụng doanh nghiệp của con cái họ; tạo điều kiện và môi trường thuận lợi cho các thành phần này phát triển trồng trọt, chăn nuôi, trồng rừng, nuôi trồng, khai thác thuỷ, hải sản, chế biến nông, lâm, thuỷ sản, kinh doanh dịch vụ nông nghiệp và mở mang ngành nghề ở nông thôn. Mọi hành vi xâm phạm các quyền nói trên đều phải xử lý theo pháp luật; các định kiến hẹp hòi đối với kinh tế cá thể, tư nhân phải được xoá bỏ". [thuvienphapluat.vn] 
Nhà nước khuyến khích cá nhân bỏ vốn, sức lao động, kỹ thuật... mở mang sản xuất; khuyến khích các hình thức hợp tác giữa các hộ gia đình, giữa người có vốn, có tư liệu sản xuất, có tay nghề với người có sức lao động; bảo đảm thực hiện đúng nguyên tắc tự nguyện, cùng có lợi, quản lý dân chủ; bảo đảm nguyên tắc công bằng trong tổ chức xí nghiệp công tư hợp doanh vì yêu cầu phát triển sản xuất, đổi mới kỹ thuật, nâng cao hiệu quả kinh tế.

Nhà nước giao quyền sử dụng một số ruộng, đất rừng và mặt nước cho các hộ gia đình để họ tổ chức sản xuất, kinh doanh theo đúng pháp luật. Đối với đất trồng rừng và cây công nghiệp dài ngày, sẽ được giao quyền sử dụng từ 1 đến 2 chu kỳ kinh doanh. Đối với mặt nước và đất trồng cây lương thực, cây công nghiệp hàng năm, thời gian đó có thể từ 15 đến 20 năm. Trong thời gian này, họ được giao quyền thừa kế sử dụng đất cho con cái và trong trường hợp chuyển sang làm nghề khác được chính quyền cho phép chuyển nhượng quyền tiếp tục sử dụng đất cho chủ khác. Các hộ gia đình và công ty tư nhân được thuê mướn lao động theo yêu cầu phát triển sản xuất và theo Luật lao động của nhà nước.

Từ khi thực hiện Nghị quyết khoán 10, người dântrong làng Hương Xạ đã yên tâm đầu tư thâm canh, xen canh tăng năng suất cây trồng. Còn những tư liệu sản xuất như: trâu, bò, cày bừa, nông cụ sản xuất của HTX được định giá và bán lại cho xã viên.

Sau khi thực hiện Nghị quyết khoán 10, người dân làng Hương Xạ đã chủ động đưa những giống lúa mới vào sản xuất nhằm tăng năng suất cây trồng như: X12, U17,...Thực hiện một phần nhiệm vụ gắn nông nghiệp với công nghiệp gắn sản xuất với thị trường nhiều hộ gia đình trong làng đã tiến hành xây dựng mô hình VAC (vườn, ao chuồng), VACR (vườn, ao, chuồng, rừng).

Ngoài phát triển trồng trọt, chăn nuôi, các ngành nghề dịch vụ ở Hương Xạ cũng từng bước được mở rộng thu hút hàng trăm lao động vào các nghề: mộc, nề, đóng gạch, xay sát, dịch vụ vật tư, hàng tiêu dùng,... Để giải quyết 
nguồn lao động thủ công, tăng thu nhập cho gia đình, nhiều hộ đã mạnh dạn đầu tư vốn mua máy xay sát phục vụ bà con nông dân. Năm 1994, làng Hương Xạ còn tiến hành giao 644,8 ha đất rừng cho gần 100 hộ.

Trong những năm gần đây, người dân làng Hương Xạ còn tập trung đầu tư vào sản xuất ván bóc, sản xuất chè để xuất khẩu, sản phẩm chè khô do công ty chè Phú Bền - Hương Xạ đã thực sự thu hút được thị trường trong và ngoài tỉnh.

Về hoạt động văn hoá: từ năm 1986, các hoạt động văn hoá của làng Hương Xạ diễn ra chủ yếu ở ngôi nhà gỗ ba gian được xây dựng năm 1986 và tại nhà trưởng thôn. Đến năm 2006, được sự quan tâm của các cấp uỷ Đảng và chính quyền các cấp, nhà văn hoá làng Hương Xạ đã nhanh chóng được triển khai xây dựng, từ đó đến nay người dân tổ chức và tham sinh hoạt cộng đồng tại nhà văn hoá.

Về tôn giáo, tín ngưỡng: Đáp ứng nhu cầu và nguyện vọng của người dân trong làng, đến năm 1993 chùa Hương Sơn đã được khôi phục lại trên nền móng cũ. Năm 2006, được sự chỉ đạo của Huyện uỷ Hạ Hoà, chùa Hương Sơn được chỉnh trang, tu sửa lại khang trang, sạch sẽ. Như vậy, chùa Hương Sơn lại tiếp tục trở thành một điểm tựa tâm linh, là niềm tự hào, niềm tin để người dân trong làng Hương Xạ hướng đến.

\section{Tiểu kết}

Hương Xạ là một ngôi làng được thành lập khá muộn, cách đây khoảng 300 năm, đơn vị hành chính và bộ máy quản lý của làng Hương Xạ luôn có sự thay đổi. Trong các giai đoạn lịch sử khác nhau đời sống kinh tế, văn hóa, chính trị, xã hội của người dân trong làng Hương Xạ cũng khác nhau. Người dân trong làng từ xưa đến nay luôn đoàn kết, giúp đỡ nhau, vì thế trước những biến cố của lịch sử, của thời đại, tinh thần cố kết cộng đồng của người dân làng Hương Xạ luôn được giữ vững, họ luôn tìm cách động viên, gắn kết nhau vượt qua mọi hoàn cảnh khó khăn, vượt qua những thiếu thốn của cuộc sống để giữ vững tình đoàn kết xóm làng. Trong mỗi thời kỳ lịch sử khác nhau họ 
lại sử dụng một không gian sinh hoạt cộng đồng khác nhau từ đình làng đến không gian hợp tác xã và hiện nay là nhà văn hóa. Tuy nhiên, đây là một khu vực thuộc vùng trung du miền núi Bắc Bộ nên điều kiện phát triển kinh tế, văn hóa của họ rất hạn chế và khó khăn, từ xưa đến nay họ chỉ biết dựa vào ruộng, dựa vào rừng để sinh sống và tồn tại; đời sống sinh hoạt của họ ngày ngày qua ngày khá đơn điệu và tẻ nhạt nên mọi hoạt động diễn ra tại không gian sinh hoạt hoạt cộng đồng của người dân làng Hương Xạ cũng không được sôi nổi là mấy. 


\section{Chương 2. NHÀ VĂN HOÁ HƯƠNG XẠ - HUYỆN HẠ HOÀ - TỈNH PHÚ THO}

\subsection{Chủ trương của Đảng và Nhà nước về xây dựng nhà văn hoá trong chương trình xây dựng nông thôn mới}

Nông thôn là nơi sinh sống của một bộ phận dân cư chủ yếu làm việc trong lĩnh vực nông nghiệp. Nước ta hiện nay vẫn là một nước nông nghiệp với hơn $70 \%$ dân cư đang sống ở nông thôn. Phát triển nông nghiệp nông thôn đã, đang và sẽ còn là mối quan tâm hàng đầu, có vai trò quyết định đối với việc ổn định kinh tế - xã hội đất nước.

Ngoài ra nông thôn Việt Nam là khu vực rộng lớn và đông dân nhất cả nước, nó cũng là nơi lưu giữ, bảo tồn các phong tục, tập quán của cộng đồng, là nơi sản xuất ra các sản phẩm cần thiết cho cuộc sống con người. Trong xu thế hiện nay, không thể chỉ tập trung phát triển công nghiệp khi nông nghiệp, nông thôn còn lạc hậu và đời sống nông dân còn thấp, xây dựng nông thôn mới là một trong những nhiệm vụ quan trọng hàng đầu của sự nghiệp công nghiệp hoá, hiện đại hoá đất nước của Đảng và nhà nước Việt Nam. Vì vậy, Nghị quyết Đại hội Đại biểu toàn quốc lần thứ $\mathrm{X}$ của Đảng xác định mục tiêu xây dựng nông thôn mới là: "Xây dựng nông thôn mới ngày càng giàu đẹp, dân chủ, công bằng, văn minh, có cơ cấu kinh tế hợp lý, quan hệ sản xuất phù hợp, kết cấu hạ tầng kinh tế - xã hội phát triển ngày càng hiện đại”. [thuvienphapluat.vn]

Nghị quyết 26/NQTW ngày 28/05/2008 đã nêu một cách tổng quát về mục tiêu, nhiệm vụ cũng như phương thức tiến hành quá trình xây dựng nông thôn mới trong giai đoạn hiện nay, phù hợp với điều kiện thực tiễn phát triển của đất nước. Quan điểm đó của Đảng là sự kế thừa và phát huy những bài học kinh nghiệm lịch sử về phát huy sức mạnh toàn dân, huy động mọi nguồn lực tạo ra sức mạnh tổng hợp xây dựng nông thôn mới. 
Quán triệt Nghị quyết Đại hội X, Hội nghị Trung Ương lần thứ bảy (khóa X) ra Nghị quyết số 26-NQ/TW, ngày 5 tháng 8 năm 2008, đã nêu một cách toàn diện chủ trương, quan điểm của Đảng ta về xây dựng nông thôn mới. Nghị quyết khẳng định nông nghiệp, nông dân, nông thôn có vai trò to lớn, có vị trí quan trọng trong sự nghiệp công nghiệp hóa, hiện đại hóa đất nước. Chính vì vậy, các vấn đề nông nghiệp, nông dân, nông thôn phải được giải quyết đồng bộ, gắn với quá trình đẩy mạnh công nghiệp hoá, hiện đại hoá.

Giải quyết vấn đề nông nghiệp, nông thôn không phải chỉ là nhiệm vụ của nông dân ở khu vực nông thôn mà là nhiệm vụ của cả hệ thống chính trị và toàn xã hội, xây dựng nông thôn mới là xây dựng kết cấu hạ tầng kinh tế xã hội hiện đại ở nông thôn, xây dựng cơ cấu kinh tế và các hình thức tổ chức sản xuất hợp lý, gắn nông nghiệp với phát triển nhanh công nghiệp, dịch vụ, đô thị theo quy hoạch. Xây dựng giai cấp nông dân, củng cố liên minh công nhân - nông dân - trí thức vững mạnh, không ngừng nâng cao đời sống vật chất, tinh thần của dân cư nông thôn để tạo sự hài hoà giữa các vùng, tạo sự chuyển biến nhanh hơn ở các vùng khó khăn; nông thôn được đào tạo có trình độ sản xuất ngang bằng với các nước tiên tiến trong khu vực và đủ bản lĩnh chính trị, đóng vai trò làm chủ nông thôn mới.

Thực hiện đường lối của Đảng, ngày 28/10/2008, Chính phủ đã ra Nghị quyết số 24/2008/NQ-CP ban hành một chương trình hành động của Chính phủ về xây dựng nông nghiệp, nông dân và nông thôn, thống nhất nhận thức, hành động về nông nghiệp, nông dân, nông thôn và Chương trình mục tiêu Quốc gia về xây dựng nông thôn mới.

Trong Chương trình mục tiêu Quốc gia về xây dựng nông thôn mới có nêu rõ quá trình xây dựng, tổ chức cuộc sống của cư dân nông thôn theo hướng văn minh, hiện đại bên cạnh việc giữ gìn bản sắc văn hóa dân tộc và môi trường sinh thái.

Trong Cương lĩnh xây dựng đất nước trong thời kỳ quá độ lên chủ nghĩa xã hội (bổ sung, phát triển năm 2011), Đảng ta khẳng định: “xây dựng 
nông thôn mới là một nhiệm vụ quan trọng trong định hướng phát triển kinh tế, xã hội của đất nước". Nghị quyết Đại hội lần thứ XI của Đảng đã nêu rõ phương hướng, nhiệm vụ của chương trình xây dựng nông thôn mới đến năm 2020 là: "Tiếp tục triển khai theo các bước đi cụ thể, vững chắc trong từng giai đoạn, giữ gìn và phát huy nét văn hoá bản sắc của nông thôn Việt Nam”. [thuvienphapluat].

Căn cứ Nghị định số 112/2007/NĐ-CP ngày 26 tháng 6 năm 2007 của Chính phủ quy định chi tiết và hướng dẫn thi hành một số điều của Luật Thể dục, thể thao.

Căn cứ Nghị định số 185/2007/NĐ-CP ngày 25 tháng 12 năm 2007 của Chính phủ quy định chức năng, nhiệm vụ, quyền hạn và cơ cấu tổ chức của Bộ Văn hóa, Thể thao và Du lịch.

Căn cứ Quyết định số 491/QĐ-TTg ngày 16 tháng 4 năm 2009 của Thủ tướng Chính phủ ban hành Bộ tiêu chí quốc gia về xây dựng nông thôn mới.

Căn cứ Quyết định số 22/QĐ-TTg ngày 05 tháng 1 năm 2010 của Thủ tướng Chính phủ phê duyệt Đề án "Phát triển văn hóa nông thôn đến năm 2010, định hướng đến năm 2020".

Căn cứ Quyết định số 800/QĐ-TTg ngày 04 tháng 6 năm 2010 của Thủ tướng Chính phủ phê duyệt Chương trình mục tiêu Quốc gia về xây dựng nông thôn mới giai đoạn 2010-2020.

Từ những Nghị quyết, nghị định được nêu ra trong chương trình xây dựng nông thôn mới có một nội dung nền tảng cần triển khai là nội dung xây dựng nhà văn hoá khu dân cư ở thôn, làng, ấp, bản,...

Triển khai xây dựng nhà văn hoá là một chương trình, một nội dung quan trọng giúp nâng cao đời sống vật chất và tinh thần cho người dân ở mọi miền đất nước, giúp bảo tồn và duy trì bản sắc văn hoá vùng miền và là nơi để triển khai các chủ trường, đường lối của Đảng, chính sách, pháp luật của Nhà nước. 
Ngày 8/3/2011, Bộ Văn hóa Thể thao và Du lịch ban hành thông tư: 06/2008/TT-BVHTTDL quy định mẫu về tổ chức, hoạt động và tiêu chí của Nhà văn hóa - Khu thể thao thôn, làng, ấp, bản, buôn, plây, phum, sóc (sau đây gọi chung là Nhà văn hóa - Khu thể thao thôn) như sau:

Điều 1: Phạm vi điều chỉnh, đối tuợng áp dụng

1.Thông tư 06/2011/TT-BVHTTDL ngày 8/3/2011 quy định mẫu về tổ chức, hoạt động và tiêu chí của Nhà văn hóa - Khu thể thao thôn.

2. Thông tư này không áp dụng đối với Nhà văn hóa - Khu thể thao của tổ dân phố (khu phố, khối phố, khu dân cư ở đô thị); Nhà văn hóa - Khu thể thao của các cơ quan, đơn vị, doanh nghiệp và các cơ sở xã hội hóa khác trong lĩnh vực văn hóa, thể thao và du lịch đóng trên địa bàn thôn.

Điều 2. Tên gọi, vị trí, chức năng

1. Tên gọi: Nhà văn hóa - Khu thể thao + tên thôn

2. Vị trí: Nhà văn hóa - Khu thể thao thuộc hệ thống thiết chế văn hóa thể thao cơ sở của cả nước; do Chủ tịch UBND xã quyết định thành lập, lãnh đạo toàn diện. Trưởng thôn trực tiếp quản lý, chịu sự hướng dẫn về nghiệp vụ của Trung tâm Văn hóa-Thể thao cấp trên.

3. Chức năng

1. Nhà văn hoá góp phần tuyên truyền, phổ biến chủ trương, đường lối của Đảng, chính sách, pháp luật của Nhà nước; kiến thức khoa học, kỹ thuật; giáo dục tư tưởng, đạo đức, lối sống, nếp sống văn hóa lành mạnh trên địa bàn thôn.

2. Nhà văn hoá dân cư là nơi tổ chức sinh hoạt văn hóa, văn nghệ, thể dục, thể thao, vui chơi giải trí, nâng cao mức hưởng thụ văn hóa của nhân dân, góp phần xây dựng nông thôn mới.

3. Nhà văn hoá dân cư là nơi tổ chức hội họp, học tập cộng đồng và tổ chức các hoạt động sinh hoạt khác ở thôn.

Điều 3: Nhiệm vu 
1. Xây dựng kế hoạch, chương trình hoạt động ngắn hạn, dài hạn trình lên Chủ tịch Ưy ban nhân dân xã và tổ chức thực hiện sau khi phê duyệt.

2. Tổ chức các hoạt động tuyên truyền, cổ động phục vụ các nhiệm vụ chính trị, sản xuất và đời sống của nhân dân ở thôn.

3. Tổ chức các hoạt động văn nghệ, thể dục, thể thao quần chúng, cuộc giao lưu, liên hoan, hội diễn văn nghệ; giao hữu, thi đấu các môn thể thao; duy trì hoạt động các loại hình câu lạc bộ, nhóm; phát hiện bồi dưỡng năng khiếu văn hóa, văn nghệ, thể dục, thể thao và các hoạt động vui chơi, giải trí cho trẻ em.

4. Tổ chức các chương trình, lớp học nâng cao dân trí, tiếp nhận thông tin và hoạt động dịch vụ phục vụ nhân dân trên địa bàn thôn.

5. Tham gia các hoạt động xây dựng gia đình văn hóa, nếp sống văn hóa, xây dựng nông thôn mới.

6. Xây dựng cơ sở vật chất, đầu tư trang thiết bị, quản lý khai thác và sử dụng hiệu quả công trình.

7. Tổ chức các cuộc họp của thôn.

8. Thực hiện các nhiệm vụ khác do lãnh đạo địa phương giao.

Điều 4: Cơ cấu tổ chức

1. Căn cứ tình hình kinh tế - xã hội của địa phương, trưởng thôn tổ chức bầu chọn Chủ nhiệm hoặc Ban Chủ nhiệm Nhà văn hóa - Khu thể thao thôn.

Chủ nhiệm hoặc Ban Chủ nhiệm Nhà văn hóa - Khu thể thao thôn hoạt động theo nguyên tắc kiêm nhiệm, tự quản, tự trang trải từ nguồn kinh phí xã hội hóa và hỗ trợ của ngân sách xã.

2. Có đội ngũ cộng tác viên và người hoạt động nghiệp vụ chuyên trách.

Điều 5: Cơ sở vật chất, trang thiết bị, chuyên trách 
1. Cơ quan có thẩm quyền ở địa phương có trách nhiệm cấp đất xây dựng Nhà văn hóa - Khu thể thao thôn theo quy hoạch đã được duyệt và được sử dụng đúng mục đích.

2. Nhà văn hóa - Khu thể thao thôn được xây dựng ở vị trí trung tâm tạo thuận lợi cho nhân dân tham gia sinh hoạt.

3. Kiến trúc Nhà văn hóa - Khu thể thao phải phù hợp với điều kiện kinh tế - xã hội và bản sắc văn hóa của địa phương.

4. Quy hoạch và từng bước triển khai xây dựng sân khấu ngoài trời, sân chơi, bố trí vườn hoa, cây cảnh, hồ nước, ghế đá,...

5. Trang thiết bị tối thiểu cho các hoạt động của Nhà văn hóa - Khu thể thao gồm: hệ thống âm thanh, ánh sáng, phông màn, bàn ghế, sách báo, các dụng cụ thể thao và các loại nhạc cụ phù hợp.

\section{Kinh phí}

Kinh phí xây dựng cơ sở vật chất:

Do ngân sách Trung ương hỗ trợ một phần (căn cứ vào điểm $b$, khoản 3, mục 6 của Quyết định số 800/QĐ-TTg, ngày 04 tháng 6 năm 2011 của Thủ tướng Chính phủ phê duyệt Chương trình mục tiêu Quốc gia về xây dựng nông thôn mới giai đoạn 2010-2020); ngân sách địa phương (tỉnh, huyện, xã) hỗ trợ; nhân dân tự nguyện đóng góp; huy động từ các tổ chức, doanh nghiệp.

- Kinh phí chi tiêu các hoạt động thường xuyên: Do ngân sách địa phương hỗ trợ và nhân dân tự nguyện đóng góp.

Điều 6. Tiêu chí của Nhà văn hóa - Khu thể thao thôn

\begin{tabular}{|c|c|c|c|c|}
\hline \multirow{2}{*}{ STT } & \multirow{2}{*}{ Tiêu chí } & \multirow{2}{*}{ Nội dung tiêu chí } & \multicolumn{2}{|c|}{ Tiêu chí theo vùng } \\
\hline & & & Đồng bằng & Miền núi \\
\hline \multirow[t]{2}{*}{1} & $\begin{array}{l}\text { Diện tích đất } \\
\text { quy hoạch }\end{array}$ & $\begin{array}{l}\text { 1.1. Diện tích đất xây dựng nhà } \\
\text { văn hóa }\end{array}$ & $\begin{array}{c}\text { Từ } 500 \mathrm{~m}^{2} \text { trở } \\
\text { lên }\end{array}$ & Từ $300 \mathrm{~m}^{2}$ trở lên \\
\hline & & 1.2. Diện tích khu thể thao & $\begin{array}{c}\text { Từ } 2.000 \mathrm{~m}^{2} \text { trở } \\
\text { lên }\end{array}$ & Từ $1.500 \mathrm{~m}^{2}$ trở lên \\
\hline
\end{tabular}




\begin{tabular}{|c|c|c|c|c|}
\hline \multirow[t]{2}{*}{2} & \multirow[t]{2}{*}{ Quy mô xây } & \multirow{2}{*}{$\begin{array}{l}\text { 2.1. Hội trường nhà văn hóa } \\
\text { 2.2. Sân khấu trong hội trường }\end{array}$} & \multirow{2}{*}{\begin{tabular}{|c|}
$\begin{array}{c}\text { Từ } 100 \text { chỗ } \\
\text { ngồi trở lên }\end{array}$ \\
Từ $30 \mathrm{~m}^{2}$ trở lên
\end{tabular}} & \multirow{2}{*}{\begin{tabular}{|c|c} 
Từ 80 chỗ ngồi trở \\
lên
\end{tabular}} \\
\hline & & & & \\
\hline & & 2.3. Sân tập thể thao & $\begin{array}{c}\text { Từ } 250 \mathrm{~m}^{2} \text { trở } \\
\text { lên }\end{array}$ & Từ $200 \mathrm{~m}^{2}$ trở lên \\
\hline & & $\begin{array}{l}\text { 2.4. Công trình phụ trợ Nhà văn } \\
\text { hóa - Khu thể thao (nhà để xe, khu } \\
\text { vệ sinh, vườn hoa, cổng, tường rào } \\
\text { bảo vệ) }\end{array}$ & Bắt buộc có đủ & Bắt buộc có đủ \\
\hline & & $\begin{array}{l}\text { 2.5. Có thể xây dựng những công } \\
\text { trình thể thao khác được quy định } \\
\text { tại Nghị định số } 112 / 2007 / \mathrm{N} Đ-\mathrm{CP} \\
\text { ngày } 26 / 6 / 2007 \text { của Chính phủ, } \\
\text { quy định chi tiết và hướng dẫn thi } \\
\text { hành một số điều của Luật Thể } \\
\text { dục, thể thao. }\end{array}$ & Không bắt buộc & Không bắt buộc \\
\hline 3 & Trang thiết bị & $\begin{array}{l}\text { 3.1. Trang bị của hội trường Nhà } \\
\text { văn hóa: } \\
\text { Bộ tăng âm (tivi, ampli, micro, } \\
\text { loa) } \\
\text { Bộ trang trí, khánh tiết: cờ Tổ } \\
\text { quốc, cờ Đảng, ảnh hoặc tượng } \\
\text { Bác Hồ, phông màn sân khấu nhỏ, } \\
\text { băng khẩu hiệu, cờ trang trí... } \\
\text { Bàn, ghế phục vụ sinh hoạt } \\
\text { Tủ sách, tranh ảnh tuyên truyền } \\
\text { phục vụ thiếu nhi } \\
\text { - Bảng tin, nội quy hoạt động } \\
\text { Một số nhạc cụ phổ thông, truyền } \\
\text { thống phù hợp với địa phương. }\end{array}$ & Có đủ & Yêu cầu : đạt $80 \%$ \\
\hline
\end{tabular}




\begin{tabular}{|c|c|c|c|c|}
\hline & & $\begin{array}{l}\text { 3.2. Dụng cụ thể thao: Một số } \\
\text { dụng cụ thể thao phổ thông và } \\
\text { dụng cụ thể thao truyền thống phù } \\
\text { hợp với phong trào thể thao quần } \\
\text { chúng ở địa phương }\end{array}$ & $\begin{array}{l}\text { Có đủ các dụng } \\
\text { cụ TDTT theo } \\
\text { nhu cầu sử } \\
\text { dụng }\end{array}$ & $\begin{array}{l}\text { Có các dụng cụ } \\
\text { thể thao tối thiểu }\end{array}$ \\
\hline 4 & $\begin{array}{l}\text { Kinh phí hoạt } \\
\text { động thường } \\
\text { xuyên }\end{array}$ & $\begin{array}{l}\text { 4.1. Ngân sách địa phương hỗ trợ } \\
\text { 4.2. Kinh phí do nhân dân đóng } \\
\text { góp và xã hội hóa }\end{array}$ & $\begin{array}{l}\text { Tỷ lệ cụ thể do } \\
\text { địa phương quy } \\
\text { định }\end{array}$ & $\begin{array}{l}\text { Tỷ lệ cụ thể do địa } \\
\text { phương quy định }\end{array}$ \\
\hline \multirow[t]{2}{*}{5} & \multirow[t]{2}{*}{$\begin{array}{c}\text { Cán bộ nghiệp } \\
\text { vụ }\end{array}$} & 5.1. Trình độ chuyên môn & Sơ cấp trở lên & $\begin{array}{c}\text { Qua lớp bồi dưỡng } \\
\text { nghiệp vụ }\end{array}$ \\
\hline & & 5.2. Chế độ thù lao & $\begin{array}{l}\text { Hưởng thù lao } \\
\text { theo công việc }\end{array}$ & $\begin{array}{l}\text { Hưởng thù lao } \\
\text { theo công việc }\end{array}$ \\
\hline \multirow[t]{3}{*}{6} & \multirow[t]{3}{*}{$\begin{array}{l}\text { Kết quả thu } \\
\text { hút nhân dân } \\
\text { tham gia hoạt } \\
\text { động }\end{array}$} & $\begin{array}{l}\text { 6.1. Hoạt động văn hóa văn nghệ } \\
\text { thường xuyên }\end{array}$ & $\begin{array}{c}50 \% \text { trở } \\
\text { lên/tổng số dân }\end{array}$ & $\begin{array}{c}30 \% \text { trở } \\
\text { lên/tổngsố dân }\end{array}$ \\
\hline & & $\begin{array}{l}\text { 6.2. Hoạt động thể dục thể thao } \\
\text { thường xuyên }\end{array}$ & \begin{tabular}{|c|}
$25 \%$ trở \\
lên/tổng số dân
\end{tabular} & $\begin{array}{c}15 \% \text { trở lên/tổng } \\
\text { số dân }\end{array}$ \\
\hline & & $\begin{array}{l}\text { 6.3. Hoạt động văn hóa, vui chơi, } \\
\text { giải trí phục vụ cho trẻ em }\end{array}$ & $\begin{array}{c}30 \% \text { thời gian } \\
\text { hoạt động }\end{array}$ & $\begin{array}{c}20 \% \text { thời gian } \\
\text { hoạt động }\end{array}$ \\
\hline
\end{tabular}

\section{Điều 7: Tổ chức thục hiện}

1. Căn cứ Thông tư 06/2011/TT-BVHTTDL và các văn bản quy phạm pháp luật có liên quan, Ủy ban nhân dân các tỉnh, thành phố trực thuộc Trung ương trình Hội đồng nhân dân cùng cấp, ban hành chính sách về sử dụng đất, mức kinh phí đầu tư, hỗ trợ từ nguồn ngân sách Nhà nước; chế độ thù lao của cán bộ, cộng tác viên; chính sách thực hiện xã hội hóa văn hóa xây dựng Nhà văn hóa - Khu thể thao thôn. 
2. Các cơ quan, đơn vị Văn hóa, Thể thao và Du lịch của Nhà nước ở Trung ương và địa phương chỉ đạo, hướng dẫn về chuyên môn nghiệp vụ, đào tạo, bồi dưỡng cán bộ, cộng tác viên quản lý Nhà văn hóa - Khu thể thao thôn.

Điều 8: Hiệu lục thi hành

1. Thông tư này có hiệu lực thi hành từ ngày 01 tháng 5 năm 2011.

2. Trong quá trình thực hiện, nếu có vấn đề phát sinh hoặc vướng mắc đề nghị phản ánh kịp thời về Bộ Văn hóa, Thể thao và Du lịch để nghiên cứu, bổ sung và chỉnh sửa cho phù hợp.

Như vậy, trong kế hoạch triển khai xây dựng nông thôn mới của Đảng và Nhà nước đã miêu tả rất chi tiết, rất cụ thể nội dung xây dựng nhà văn hoá khu dân cư, đây là một công trình mới, một không gian văn hoá mới được áp dụng rộng khắp trên đất nước Việt Nam.

\subsection{Nhà văn hoá Hương $X a ̣$}

\subsection{1. Đời sống văn hóa của cu dân Hương Xạ trước khi có nhà văn hóa}

Trải qua gần 20 năm, vai trò của hợp tác xã nông nghiệp Hương Xạ đã không còn như trước, các hoạt động văn hoá cộng đồng được tổ chức tại hợp tác xã nông nghiệp Hương Xạ trước kia chỉ còn lại trong kí ức. Vì thế, trước khi có nhà văn hóa đời sống văn hóa của cư dân Hương Xạ khá khó khăn, họ tổ chức sinh hoạt cộng đồng ở ngôi nhà lá ba gian được xây dựng trên nền sân kho hợp tác xã hoặctại nhà trưởng khu.

Ngày đó, đời sống văn hóa của cư dân Hương Xạ chủ yếu thực hiện thông qua bản quy ước của làng. Bản quy ước của làng Hương Xạ, gồm có 5 chương, 45 điều:

Chương 1 : Những quy định chung

Chương 2: Phát triển kinh tế, quản lý đất đai, tài nguyên khoáng sản

Chương 3: Quy định về đời sống văn hóa trong việc hiếu - việc hỷ - lễ hội - mừng thọ - tín ngưỡng và thực hiện cuộc vận động toàn dân đoàn kết xây dựng đời sống ở khu dân cư.

Chương 4: An ninh trật tự. 
Chương 5: Quy định về khen thưởng và xử lý vi phạm.

Trong bản quy ước nêu rõ tiêu chuẩn để đạt một gia đình văn hóa là xây dựng gia đình có cuộc sống ấm no, hòa thuận, tiến bộ, khỏe mạnh, hạnh phúc; thực hiện tốt nghĩa vụ công dân; đoàn kết tương trợ, giúp đỡ nhau trong cuộc sống cộng đồng; thực hiện tốt chính sách dân số - kế hoạch hóa gia đình; mọi thành viên trong gia đình phải tôn trọng nhau. Mọi người trong làng Hương Xạ phải yêu thương, đùm bọc, giúp đỡ lẫn nhau, tích cực học tập nâng cao trí tuệ và thực hiện tốt công tác giáo dục. Mỗi cá nhân phải có trách nhiệm bảo vệ an ninh tổ quốc, giữ vững an ninh trật tự xã hội, đấu tranh phòng ngừa, tố giác tội phạm, tạo mọi điều kiện giúp đỡ lực lượng Công an nhân dân thực hiện nhiệm vụ và giải quyết các vụ việc vi phạm. Cán bộ và nhân dân trong làng Hương Xạ phải duy trì tốt phong trào văn hóa - văn nghệ, thể dục - thể thao, thường xuyên tổ chức luyện tập và tham gia biểu diễn, hội diễn, hội thể thao nhằm thúc đẩy phong trào và thu hút đông đảo nhân dân địa phương cùng tham gia.

Nhưng chính vì không có không gian sinh hoạt cố định nên đời sống văn hóa của cư dân Hương Xạ trước đây chủ yếu được thực hiện thông qua bản quy ước làng.

\subsubsection{Triển khai xây dụng nhà văn hoá Hương Xạ theo quy định của Nhà nước}

Xây dựng đời sống văn hóa ở khu dân cư là nội dung quan trọng của Đảng và Nhà nước. Xây dựng đời sống văn hóa ở khu dân cư sẽ giúp đề cao các chuẩn mực đạo lý và truyền thống của dân tộc, từ đó điều chỉnh các mối quan trong gia đình và trong xã hội để tiến tới một xã hội tiến bộ, lành mạnh, văn minh.

Năm 2006, UBND xã Hương Xạ - huyện Hạ Hòa - tỉnh Phú Thọ nhận được công văn của cấp trên về việc triển khai xây dựng hệ thống các nhà văn hóa tại xã Hương Xạ, gồm 13 nhà văn hoá tại 13 khu dân cư trên địa bàn xã. 
Trong kế hoạch triển khai xây dựng 13 nhà văn hoá tại xã Hương Xạ thì nhà văn hoá khu dân cư số 3 là nhà văn hoá được Đảng bộ và nhân dân trong xã thống nhất triển khai xây dựng thí điểm với bốn lí do:

1. Khu dân cư số 3 là tên gọi của ngôi làng Hương Xạ, một ngôi làng có cái tên trùng với tên xã.

2. Khu dân cư số 3 có vị trí thuận lợi nhất trong xã Hương Xạ.

3. Khu dân cư số 3 là khu dân cư có số dân đông nhất trong xã.

4. Khu dân cư số 3 là khu dân cư được biết đến nhiều nhất trong lịch sử xã Hương Xạ: Nơi lưu giữ dấu ấn của ngôi chùa Hương Sơn, nơi lưu giữ kí ức của ngôi đình làng Hương $X a ̣$, nơi lưu trú của bộ đội trong kháng chiến, ...

Được sự thống nhất của Đảng bộ và nhân dân trong xã, nhà văn hoá khu dân cư số 3 - xã Hương Xạ đã được lựa chọn là nhà văn hoá trung tâm của xã, nó có thể được gọi bằng tên "nhà văn hoá Hương Xạ" thay cho tên "nhà văn hoá khu dân cư số 3".

Đây cũng chính là lý do để tôi căn cứ lựa chọn nhà văn hoá khu dân cư số 3, xã Hương Xạ để nghiên cứu.

Kế hoạch triển khai xây dụng nhà văn hoá Hưong Xạ, tại khu dân cu số 3:

- Các nguyên tắc cơ bản

Nhà văn hóa Hương Xạ là tài sản do cán bộ và nhân dân trong làng Hương xạ xây dựng nên vì thế nhà văn hoá Hương Xạ sẽ được Ủy ban nhân dân xã Hương Xạ giao cho khu dân cư số 3 quản lý, sử dụng trong việc thực hiện các nhiệm vụ chính trị, kinh tế, văn hóa, xã hội và các mục đích phục vụ cộng đồng. Đây là công trình công cộng phải được quản lý, sử dụng có hiệu quả với ý thức trách nhiệm cao của tất cả cán bộ và nhân dân trên địa bàn.

Nhà văn hóa Hương Xạ cần phải thường xuyên được tu bổ, nâng cấp, bổ sung cả về tài sản, trang thiết bị để phục vụ cho nhiệm vụ chính trị, văn hóa tinh thần của nhân dân trong làng. 
- Chức năng: nhà văn hóa Hương Xạ sẽ là nơi sinh hoạt của tất cả người dân đang sinh sống, làm việc và cư trú tại làng Hương Xạ (khu dân cư số 3).

- Nhiệm vụ: Nhà văn hóa Hương Xạ sẽ là nơi phục vụ các chương trình đại hội, hội nghị của tổ chức Đảng, chính quyền, các ban ngành, đoàn thể, tổ chức xã hội của khu dân cư, các hội nghị, hội thảo được người dân tự tổ chức theo đúng quy định của pháp luật. Các chương trình, các hoạt động diễn ra phải đảm bảo không gây ảnh hưởng đến tình hình chính trị, an ninh quốc phòng và trật tự an toàn xã hội.

Tại đây sẽ diễn ra các hoạt động văn hóa, văn nghệ, thể dục, thể thao phục vụ cho tất cả người dân đang sinh sống, làm việc và cư trú trong làng.

Các buổi giao lưu văn nghệ, thể dục, thể thao trong tất cả các ngày lễ kỷ niệm, các ngày trọng đại của đất nước như: ngày Quốc lễ (10-3 âm lịch), ngày thành lập Đoàn TNCS Hồ Chí Minh (26-3), ngày Giải phóng miền Nam (30-4), ngày Quốc tế lao động (1-5), ngày Tết thiếu nhi (1-6), ngày cử tri đi bầu cử,...cũng sẽ được tổ chức tại đây.

Nhà văn hóa cũng sẽ là nơi chính quyền phải thường xuyên mở các lớp học, lớp tập huấn và các buổi sinh hoạt cộng đồng cho bà con như: Cách chọn giống lúa, giống cây trồng cho năng suất cao; cách phòng bệnh cho lúa; cách vệ sinh chuồng trại; cách phòng chống cháy rừng;... Các chương trình, các hoạt động này phải dược tổ chức ít nhất mỗi tháng 1 lần.

- Quyền hạn

Ban quản lý nhà văn hóa Hương Xạ sẽ trực tiếp quản lý và chịu trách nhiệm trước UBND xã và nhân dân về tài sản cố định, vật dụng của nhà văn hóa và diện tích đất được Nhà nước giao. Ban quản lý nhà văn hóa Hương Xạ cần phân công người bảo vệ và theo dõi sổ sách và các hoạt động diễn ra tại nhà văn hóa.

- Chế độ quản lý, sủ dụng nhà văn hóa 
Nhà văn hóa Hương Xạ phải được đảm bảo có tường rào bao quanh, khuôn viên sạch sẽ,... Hàng năm, cán bộ và người dân trên địa bàn cần có trách nhiệm xây dựng, tu bổ, sửa chữa, chỉnh trang nhà văn hóa để đảm bảo an toàn, tiết kiệm.

Nhà văn hoá Hương Xạ phải thường xuyên được kiểm tra, thực hiện tốt công tác an toàn (đường điện, nước, trang thiết bị) phòng chống cháy nổ, phòng kẻ gian đột nhập trộm cắp tài sản.

Hàng năm, cán bộ và nhân dân trên địa bàn cần tổ chức các cuộc hội thảo để cùng nhau bàn bạc, thống nhất nguồn quỹ tu bổ, sửa chữa, chỉnh trang, mua mới các thiết bị, đồ dùng đảm bảo cho hoạt động của nhà văn hóa được diễn ra đều đặn, cần đảm bảo công khai, dân chủ và có sự thống nhất cao. Cán bộ và nhân dân cần phối hợp làm tốt công tác tuyên truyền nâng cao ý thức trách nhiệm của người dân về quản lý, sử dụng nhà văn hóa Hương Xạ. nhà văn hóa Hương Xạ sẽ mở cửa từ $5 \mathrm{~h}$ sáng và đóng cửa trước $23 \mathrm{~h}$.

- Điều khoản thục hiện

Mọi cán bộ, người dân sống trong trên địa bàn cần phải có trách nhiệm thực hiện những quy định, quy chế đã đề ra, phải có ý thức trách nhiệm trong việc xây dựng, quản lý, sử dụng nhà văn hóa Hương Xạ cho hiệu quả và đúng mục đích.

Cán bộ, cá nhân, hộ gia đình trong khu dân cư luôn luôn chấp hành đúng các quy định, quy chế được đặt ra tại nhà văn hoá Hương Xạ. Nếu có trường hợp vi phạm phải được xử lý công khai, minh bạch. Nếu các trường hợp vi phạm ở mức độ nhẹ thì sẽ nhắc nhở, phê bình, trường hợp vi phạm ở mức độ nặng thì phải đề nghị các cấp có thẩm quyền xem xét và xử lý. Những quy định, quy chế này sẽ được thông qua ở hội nghị toàn dân và sẽ được trình lên UBND xã Hương Xạ phê duyệt trước khi tiến hành thực hiện vào năm 2007. Trong quá trình tổ chức thực hiện nếu có vướng mắc, cần đề nghị UBND xã Hương Xạ xem xét, điều chỉnh, bổ sung kịp thời. 
Từ khi triển khai xây dựng nhà văn hóa khu dân cư trên địa bàn xã Hương Xạ, đến năm 2015 xã Hương Xạ đã hoàn thành xây dựng xong 100\% nhà văn hoá trên địa bàn $13 \mathrm{khu}$ dân cư, tổng mức kinh phí xây dựng là 1.114.859.000đ, trong đó: tỉnh hỗ trợ là 255.600.000đ, huyện hỗ trợ 67.800.000đ, xã hỗ trợ là 68.700.000đ, nhân dân đóng góp là 622.759.000đ.

Trong 13 nhà văn hóa được xây dựng trên địa bàn xã Hương Xạ, có 2 nhà văn hóa thực hiện tốt tiến độ đề ra là nhà văn hóa khu 3 (nhà văn hóa Hương $\mathrm{Xạ}$ ) và nhà văn hóa khu 10 . Đây là hai nhà văn hóa hoàn thành sớm nhất, ngoài ra hai nhà văn hóa này cũng đáp ứng đủ yêu cầu về diện tích (trên $80 \mathrm{~m} 2$ ), bên trong có bàn ghế, tăng âm, loa đài,...Còn 11 nhà văn hóa còn lại đều chưa đạt yêu cầu về thời gian xây dựng và trang thiết bị bên trong. Quá trình xây dựng các nhà văn hóa này đều diễn ra từ 2 đến 3 năm; một số nhà văn hóa được xây dựng quá xa khu dân cư như nhà văn hóa khu 2,5,6; một số nhà văn hóa chưa được quét ve như nhà văn hóa khu 1,4,10; một số nhà văn hóa chưa đủ trang thiết bị bên trong như nhà văn hóa khu 1,4,7,8,9,11.

Trong 13 nhà văn hoá khu dân cư được xây dựng trên địa bàn, xã Hương Xạ tập trung, chú trọng vào việc xây dựng thí điểm nhà văn hoá Hương Xạ tại khu dân cư 3. Nhà văn hoá Hương Xạ được triển khai xây dựng vào năm 2006, với tổng chi phí là 150 triệu, vị trí được đặt tại khu 3 - khu trung tâm.của xã Hương.Xạ.

Kể từ khi được đầu tư xây dựng nhà văn hoá Hương Xạ, nhân dân trong khu dân cư số 3 đã có địa điểm để tổ chức các hoạt động, có điều kiện gặp gỡ giao lưu văn hóa, văn nghệ, tập luyện, thi đấu thể thao góp phần thực hiện hiệu quả phong trào "Toàn dân đoàn kết xây dựng đời sống văn hóa" và tác động tích cực đến nhiệm vụ phát triển kinh tế - xã hội của địa phương.

\subsubsection{Quá trình xây dụng nhà văn hoá Hương Xạ}

Năm 2006, thực hiện chủ trương của Đảng, chính sách của Nhà nước về công tác xây dựng nhà văn hóa, ngày 22 tháng 8 năm 2006, UBND xã 
Hương Xạ ra văn bản số 1145/UBND-VH về việc xây dựng nhà văn hóa Hương Xạ.

Để hoàn thành nhiệm vụ này, Đảng bộ xã Hương Xạ đã lãnh đạo khu dân cư số 3 tổ chức họp bàn quán triệt việc thành lập ban chỉ đạo xây dựng nhà văn hóa Hương Xạ. Qua việc triển khai thực hiện, nhân dân trong làng Hương Xạ đã đồng tình ủng hộ. Nhà văn hoá Hương Xạ đã được xây dựng với tổng chi phí là 150 triệu đồng. Bên cạnh sự hỗ trợ của Nhà nước, Đảng bộ xã Hương $X a ̣$ còn vận động nhân dân và các tổ chức trên địa bàn tự nguyện đóng góp, ủng hộ tài chính để xây dựng nhà văn hóa Hương Xạ.

Lập ban chỉ đạo xây dụng nhà văn hóa: Năm 2006, ban chỉ đạo xây dựng nhà văn hóa Hương Xạ đã đứng ra thành lập một đội xây dựng gồm 12 người do ông Trần Văn Hoà làm chủ thầu. Trong vòng hơn 2 tháng (từ đầu tháng 9 đến giữa tháng 12), nhà văn hoá Hương Xạ đã nhanh chóng được hoàn thành với bốn gian nhà cấp bốn, nhà có diện tích xây dựng là $90 \mathrm{~m}^{2}$ với tổng chi phí cho là 150 triệu. Như vậy, nhà văn hoá Hương Xạ được triển khai xây dựng khá nhanh chóng, thời gian bắt đầu xây dựng là đầu tháng 9 năm 2006 và đến tháng 12 năm 2006 đã được xây dựng xong.

\section{Kết quả thực hiện}

Năm 2006, nhà văn hoá Hương Xạ được xây dựng với quy mô, thiết kế theo sự hướng dẫn của ngành Văn hoá Thông tin nhưng vẫn chưa đáp ứng đủ nhu cầu trang thiết bị, các thiết chế bên trong còn thiếu nhiều.

Năm 2014, Uỷ ban nhân dân huyện Hạ Hoà đã ban hành kế hoạch 684/kh-UBND, ngày 07/7/2014 về chỉnh trang, tu sửa nhà văn hóa khu dân cư, trong đó có nhà văn hoá Hương Xạ. Được sự quan tâm của Huyện uỷ Hạ Hoà và sự chỉ đạo trực tiếp của UBND xã, Đảng bộ xã Hương Xạ đã chủ động tham mưu với cấp ủy, xin ý kiến chỉ đạo triển khai các văn bản hướng dẫn về nội dung, mục đích, ý nghĩa của công tác chỉnh trang, tu sửa nhà văn hóa Hương Xạ. 
Ban lãnh đạo xã quyết định thành lập tổ công tác, phân công nhiệm vụ đồng thời cử cán bộ xuống địa bàn khu dân cư số 3 để trực tiếp kiểm tra, đánh giá thực trạng, thực tế các hạng mục công trình xây dựng tại nhà văn hoá Hương Xạ, sau đó sẽ tổng hợp, báo cáo với lãnh đạo UBND xã. Cuối cùng ban lãnh đạo xã Hương Xạ chỉ đạo, hỗ trợ ngân sách và tiến hành triển khai thực hiện công tác chỉnh trang, tu sửa nhà văn hóa khu dân cư theo đúng kế hoạch đề ra.

Phối hợp chặt chẽ với Ủy ban Mặt trận Tổ quốc và các ban ngành đoàn thể địa phương, khu dân cư số 3 đã làm tốt công tác tuyên truyền, vận động các đoàn viên, hội viên và nhân dân ủng hộ bằng cách đóng góp tiền, vật liệu, cây giống, ngày công lao động để chuẩn bị chỉnh trang, tu sửa lại nhà văn hoá Hương Xạ.

Xã Hương Xạ đã chấp hành thực hiện kế hoạch 684/kh-UBND của huyện Hạ Hoà đề ra, tại đây quá trình sửa sang nhà văn hoá Hương Xạ được tiến hành rất khẩn trương, kịp thời.

Nội dung chỉnh trang, tu sửa: Tổ chức làm vệ sinh khuôn viên nhà văn hóa, làm bờ rào, trồng cây xanh, trồng cây bóng mát, san lấp bổ sung mặt bằng khuôn viên, sửa chữa lại mái nhà bị hỏng, quét vôi ve tường nhà, giặt trải lại phông rèm, làm khẩu hiện băng zôn treo tường, khung ảnh tư liệu, bảng nội quy nhà văn hóa khu, mua sắm bổ sung thêm một số trang thiết bị trong nhà văn hóa, làm sân chơi thể thao, làm nhà vệ sinh, nhà để xe,...

Tổng kinh phí chỉnh trang, tu sửa nhà văn hóa Hương Xạ, năm 2014 là : 20.520 .000 đồng, trong đó :

Ngân sách xã hỗ trợ là 7.400.000đ

Xã hội hóa là 19.120.000đ

Vật tư cây cọc là 388 cây tre

Cây giống trồng hàng rào là 640 cây các loại

Ngày công lao động là 42 công 
Trong quá trình triển khai tu sửa nhà văn hoá Hương Xạ có sự đóng góp rất lớn của ông Trần Công Đô và ông Vũ Ngọc Hùng.

Ngày 12 tháng 8 năm 2014, tại địa điểm nhà văn hóa Hương Xạ đã tổ chức lễ ra quân tiến hành chỉnh trang, tu sửa nhà văn hoá. Thành phần tham dự chỉ đạo gồm có UBND, UBMTTQ, Trưởng các ban ngành đoàn thể, Bí thư chi bộ, Trưởng khu và toàn thể bà con nhân dân trong khu dân cư số 3 .

Ngày 19 tháng 9 năm 2014, nhà văn hoá Hương Xạ được xây dựng xong, ngay chiều hôm đó tổ công tác xã Hương Xạ đã đến tiến hành kiểm tra, nghiệm thu và bàn giao cho trưởng khu dân cư số 3 .

\section{Diện mạo của nhà văn hóa sau khi được tu sửa}

Nhà văn hoá Hương Xạ được xây dựng trên một khu đất trống, nằm sát tuyến đường quốc lộ 32. Mặt trước nhà văn hoá hướng về đường quốc lộ 32, mặt sau nhà văn hoá là cánh đồng lúa.

Nhà văn hoá Hương Xạ được xây dựng vào năm 2006, nhà có diện tích xây dựng là $90 \mathrm{~m}^{2}$, mái được lợp bằng ngói Fibroximang, bên trên lợp tôn màu trắng có tác dụng chống thấm, cách nhiệt và tạo dáng; chiều cao của ngôi nhà là $4,6 \mathrm{~m}$; chiều cao của nền nhà là $0,45 \mathrm{~m}$; nền nhà được láng xi măng; ngôi nhà có 3 cửa chính và 5 cửa sổ. Bên trong nhà văn hoá Hương Xạ được kê 24 chiếc ghế dài, được lắp đặt 6 chiếc quạt trần, 1 tượng Bác, 1 bục phát biểu làm bằng gỗ, 1 ti vi 21 inch, 1 bộ tăng âm, 2 chiếc loa, 2 cái micro và một lọ hoa. Trước nhà là một khoảng sân đổ bê tông rộng $100 \mathrm{~m}^{2}$, nhà văn hoá Hương Xạ chưa có tường rào và cổng.

Tượng Bác, bục phát biểu, ti vi, bộ tăng âm, loa, micro, hoa được đặt phía trên khán đài. Phía trên khán đài là một bục rộng khoảng $14 \mathrm{~m} 2$, được bài trí gọn gàng, ngăn nắp, phía trong cùng của khán đài là một tấm phông vải nền xanh nước biển, trên cùng tấm phông có treo tấm băng zôn ghi dòng chữ "Đảng cộng sản Việt Nam quang vinh", phía bên phải là tượng Bác, bên trái là bục phát biểu và ở giữa là một chiếc bàn gỗ, bên trên chiếc bàn gỗ có để ti vi, bộ tăng âm, loa, míc. Trong khán đài, tượng Bác được xem là quan trọng 
nhất, tượng Bác được được làm bằng thạch cao và được đặt trên một bệ gỗ cao $1,3 \mathrm{~m}$, phía trước bệ là một lẵng hoa nhựa đủ màu sắc.

Phía dưới hội trường là một khoảng không rộng tầm hơn $70 \mathrm{~m}^{2}$, được kê 24 chiếu ghế dài làm bằng gỗ, đây là nơi để người dân ngồi dự, thảo luận trong các buổi họp. Phía dưới hội trường có treo hai khẩu hiệu lớn, một khẩu hiệu được treo trên cùng phía bên phải tường với dòng chữ "Sống chiến đấu, lao động và học tập theo gương Bác Hồ vĩ đại", một khẩu hiệu treo trên cùng phía bên trái tường với dòng chữ "Xây dựng đời sống văn hoá ở khu dân cư, gắn với xây dựng nông thôn mới”. Ngoài ra, xung quanh tường phía hội trường nhà văn hoá Hương Xạ còn treo một khung ảnh, bên trong khung ảnh có nhiều bức ảnh về các cuộc hội thảo, hội nghị, các chương trình văn hoá, văn nghệ, thể dục, thể thao diễn ra theo từng năm, ngoài ra trên tường còn treo hai giấy khen cấp huyện, 10 giấy khen cấp xã.

Riêng cờ tổ quốc được treo trên một cột sắt cao khoảng $15 \mathrm{~m}$ ở phía trước nhà văn hoá Hương Xạ

Hiện nay nhà văn hoá Hương Xạ đã có sân chơi thể thao (sân bê tông được xây dựng phía trước nhà văn hoá), đã có đầy đủ $80 \%$ các trang thiết bị phục vụ cho việc tổ chức hội họp và vui chơi giải trí.

Nhu vậy, tính đến năm 2014 nhà văn hóa Hương Xạ đã chính thức đi vào hoạt động theo đúng quy định. Cùng với sự quan tâm chỉ đạo sát sao của Đảng ủy ngay từ khi triển khai kế hoạch xây dựng đến chỉnh trang lại nhà văn hóa Hương Xạ đã được toàn thể nhân dân ủng hộ. Nhân dân đã hiểu rõ và nhận thấy được tầm quan trọng của việc triển khai thực hiện kế hoạch.

\section{Tiểu kết}

Trong chương trình xây dựng nông thôn mới của Đảng và Nhà nước có đề ra chủ trương xây dựng nhà văn hóa trong khu dân cư, đây là một chủ trương lớn được triển khai trong nhiều năm. Chủ trương đó đã quy định rất rõ và chi tiết từ quá trình xây dựng, nội dung đến phương thức triển khai các 
hoạt động tại nhà văn hóa khu dân cư. Quá trình xây dựng nhà văn hóa Hương Xạ đã dựa trên những quy định chung để có hướng triển khai xây dựng kịp thời trong năm 2006. Mặc dù, nhân dân làng Hương Xạ đã rất nỗ lực xây dựng nhà văn hóa theo đúng tiêu chuẩn được đề ra nhưng do sự hạn chế về ngân sách nên trong năm 2006, nhà văn hóa Hương Xạ vẫn chưa đáp ứng được $100 \%$ nhu cầu là trung tâm sinh hoạt văn hóa như yêu cầu của Đảng và Nhà nước đề ra. Chính vì thế, trong năm 2014, nhà văn hóa Hương Xạ đã tiến hành chỉnh trang, tu sửa lại cho hoàn chỉnh hơn. Nhà văn hóa Hương Xạ được xây dựng lên với mong muốn sẽ là một trung tâm sinh hoạt văn hóa sôi nổi cho người dân làng Hương Xạ. Đảng, Nhà nước và nhân dân Hương Xạ luôn mong muốn nhà văn hóa Hương Xạ sẽ trở thành một không gian văn hóa hiện đại, phù hợp thời kỳ công nghiệp hóa - hiện đại hóa đất nước hiện nay. 


\section{Chương 3: HOẠT ĐộNG CỦA NHÀ VĂN HOÁ HƯƠNG XẠ VÀ NHỨNG VẤN ĐỀ ĐẶT RA}

\subsection{Về cơ chế quản lý, tổ chức các hoạt động}

Hiện nay nhà văn hoá Hương Xạ chưa có ban quản lý, mọi công việc liên quan đến tổ chức hoạt động tại nhà văn hoá đều do trưởng khu và phó trưởng khu đảm nhiệm. Trưởng khu và phó trưởng khu là hai người giữ vị trí quan trọng trong mọi hoạt động diễn ra tại nhà văn hoá Hương Xạ như: tổ chức cuộc họp; tổ chức các chương trình văn hoá, văn nghệ, thể dục, thể thao; tổ chức các hội thảo,... Trưởng khu cũng là người kiêm nghiệm cả chức trách của nhân viên phục vụ nhà văn hoá, trưởng khu là người giữ chìa khoá và người quét dọn nhà văn hoá, thường thì một tháng trưởng khu sẽ quét dọn nhà văn hoá hai lần. Khi đoàn thể nào muốn sử dụng nhà văn hoá để hội họp thì họ phải đến nhà trưởng khu hỏi trước, trưởng khu sẽ hỏi thông tin về cuộc họp và cho tiến hành cuộc họp theo yêu cầu. Hiện nay, trưởng khu nhà văn hoá Hương Xạ là ông Vũ Ngọc Hùng, trình độ học vấn của ông là 10/10, ông đang hưởng mức thu nhập trong việc trông coi và quản lý nhà văn hoá là 400.000 đồng/tháng. Phó trưởng khu là ông Cù Văn Thụ, trình độ học vấn của ông là $10 / 10$, ông đang hưởng mức thu nhập trong việc trông coi và quản lý nhà văn hoá là 300.000 đồng/tháng.

Về sụ giám sát quản lý của chính quyền: Từ năm 2012, UBND xã Hương Xạ quyết định thành lập tổ công tác kiểm tra, giám sát nhà văn hoá Hương $X a ̣$, mỗi năm tổ công tác sẽ tiến hành kiểm tra một lần vào khoảng tháng 8 , tháng 9 dương lịch.

Công tác kiểm tra lần 1 diễn ra vào sáng ngày 7 tháng 8 năm 2012 với sự có mặt của 7 đồng chí trong đội công tác kiểm tra của xã và 3 đồng chí đại diện cho khu dân cư, kết quả thu được như sau: nhà văn hoá Hương Xạ về cơ bản đã đáp ứng được nhu cầu sinh hoạt của bà con nhân dân với hệ thống ghế ngồi, quạt điện, bóng điện chiếu sáng, bộ loa đài, tượng Bác, mục phát biểu, băng zôn, khẩu hiệu,...tuy nhiên nhà văn hoá Hương Xạ vẫn cần phải xây 
dựng thêm: tường rào, sân, nhà vệ sinh, lán xe, cổng và cần trồng thêm cây xanh, hoa trong khuôn viên.

Tiếp theo là công tác kiểm tra lần 2 diễn ra vào ngày mùng 10 tháng 9 năm 2013 cũng với sự có mặt của 7 đồng chí trong đội công tác kiểm tra của xã và 3 đồng chí đại diện cho khu dân cư, kết quả thu được như sau: Về hệ thống văn bản, vẫn chưa có quy chế hoạt động nhà văn hoá, chưa có quyết định thành lập Ban quản lý nhà văn hoá bằng văn bản. Về quy mô và thiết chế của nhà văn hoá Hương Xạ, trang thiết bị, cơ sở vật chất của nhà văn hoá Hương Xạ đã đáp ứng được $80 \%$ nhu cầu cầu nhân dân, tuy nhiên hiện nay tường nhà đã bị hư hỏng cần phải quét vôi lại, quạt điện đã có 2 chiếc hỏng nên cần phải sửa chữa hoặc thay thế, hệ thống ghế ngồi cần phải sơn và sửa chữa lại cho chắc chắn hơn, hệ thống tăng âm, loa đài có hư hỏng cần sửa chữa kịp thời. Cần xây dựng thêm: tường rào, sân, nhà vệ sinh, nhà để xe, cổng đã được triển khai từ năm 2012 đến nay vẫn chưa thực hiện nên cần nhanh chóng thực hiện trong thời gian tới.

Trong công tác kiểm tra lần 3 diễn ra vào ngày 19 tháng 8 năm 2013, sau khi kiểm tra, kết quả đánh giá của tổ công tác như sau:Về hệ thống văn bản, quy chế hoạt động nhà văn hoá đã có, quyết định thành lập Ban quản lý nhà văn hoá đang dần được triển khai bằng văn bản. Tại nhà văn hoá Hương Xạ đã đầu tư xây dựng tương đối đầy đủ hạng mục công trình như: nhà, sân, nhà vệ sinh, cây xanh. Các thiết chế trong nhà văn hoá Hương Xạ cũng đã đầy đủ. Tuy nhiên nhà văn hoá Hương Xạ vẫn còn những hạn chế như: diện tích khuôn viên bên ngoài và chưa có rào xung quanh, chưa có cổng,...

\subsection{Hoạt động của nhà văn hoá Hương Xạ}

Sau khi xây dựng xong, trong hai năm 2007 và 2008, nhà văn hoá Hương Xạ đã nhanh chóng đi vào hoạt động với nhiều chương trình, hoạt động được diễn ra như:

- Tổ chức đêm giao lưu văn nghệ mừng ngày Tết nguyên đán diễn ra vào đêm mùng 2 Tết. 
- Tổ chức cuộc thi đấu bóng chuyền giữa thanh niên làng Hương Xạ với cán bộ xã Hương Xạ, diễn ra vào mùng 3 Tết.

- Tổ chức các cuộc họp lấy ý kiến dân về việc bầu chọn trưởng khu và phó trưởng khu; tổ chức các buổi sinh hoạt dân cư với tần xuất 2 tuần/1 lần.

- Tổ chức cuộc thi gói bánh chưng nhân kỷ niệm ngày quốc lễ mùng 10 tháng 3.

- Tổ chức buổi toạ đàm hướng dẫn bà con cách vệ sinh an toàn thực phẩm do huyện Hạ Hoà tổ chức.

- Tổ chức các buổi sinh hoạt hè cho thiếu nhi vào các tháng 6,7,8 (diễn ra vào tối thứ 7 hàng tuần)

- Tổ chức văn nghệ đón Tết thiếu nhi và Tết Trung thu cho các em thiếu nhi trong làng.

- Tổ chức giao lưu văn nghệ trong các ngày lễ như: ngày thành lập Đoàn 26 tháng 3, Quốc Khánh mùng 2 tháng $9, \ldots$.

Các hoạt động văn hoá, văn nghệ, thể dục, thể thao tại nhà văn hoá Hương Xạ trong hai năm 2007 và 2008 diễn ra rất nhộn nhịp và tưng bừng.

Đến năm 2009, 2010, 2011 tần suất và thời gian diễn ra các hoạt động văn hoá, văn nghệ, thể dục, thể thao tại nhà văn hoá Hương Xạ đã giảm đi đáng kể, một số hoạt động đã ngừng hẳn như: Cuộc thi gói bánh chưng; cuộc họp bầu trưởng khu, phó trưởng khu; buổi toạ đàm vệ sinh an toàn thực phẩm; tổ chức giao lưu văn nghệ trong ngày lễ; các buổi sinh hoạt khu dân cư diễn ra với tần suất ít hơn ( 2 tháng/3 lần).

Đến năm 2012, 2013, các hoạt động diễn ra tại nhà văn hoá Hương Xạ ngày càng ít hơn so với 3 năm trước đó, hơn thế các hoạt động, các chương trình được tổ chưc, tiến hành rất sơ sài: Các chương trình văn hoá văn nghệ giao lưu chào mừng Tết nguyên đán không có người dẫn chương trình; trong ngày Tết thiếu nhi, Tết Trung thu không được tổ chức chu đáo như các năm trước, hoạt động chủ yếu là thanh niên đại diện lên chia kẹo cho cho các em; các buổi sinh hoạt hè cho các em thiếu nhi 1 tháng chỉ tổ chức sinh hoạt 1 lần. 
Năm 2014, quá trình chỉnh trang, tu sửa nhà văn hóa Hương Xạ diễn ra, vì thế năm 2015 nhà văn hóa Hương Xạ lại trở lại hoạt động với vai trò là một không gian sinh hoạt cộng đồng. Sau đây là bảng quá trình hoạt động tại nhà văn hóa Hương Xạ trong năm 2015.

Bảng: Các hoạt động diễn ra tại nhà văn hóa Hương Xạ trong năm 2015

\begin{tabular}{|c|c|l|}
\hline STT & Thời gian & \multicolumn{1}{|c|}{ Nội dung hoạt động } \\
\hline 1 & Tháng 1 & $\begin{array}{l}\text { Triển khai công tác vệ sinh đường làng ngõ xóm chuẩn } \\
\text { bị đón Tết Nguyên đán. }\end{array}$ \\
\hline 2 & Tháng 2 & $\begin{array}{l}\text { - Tổ chức cuộc thi đấu thể thao mừng xuân mới. } \\
- \text { Họp bàn cuộc thi gia đình văn hóa trong năm 2015. }\end{array}$ \\
\hline 3 & Tháng 3 & $\begin{array}{l}\text { - Diễn ra cuộc họp dân cư phổ biến Nghị quyết số } \\
77 / 2014 / \text { QH13 về Kế hoạch phát triển kinh tế - xã hội } \\
\text { năm 2015. } \\
- \text { Kỷ niệm ngày thành lập Đoàn TNCS Hồ Chí Minh } \\
26 / 3 .\end{array}$ \\
\hline 4 & Tháng 4 & $\begin{array}{l}\text { - Họp bàn, thảo luận đưa ra các nội quy, quy định nội } \\
\text { bộ của làng. } \\
- \text { Tổ chức cuộc giao lưu văn nghệ kỷ niệm ngày giải } \\
\text { phóng miền Nam 30-4. }\end{array}$ \\
\hline 5 & Tháng 6,7,8 & $\begin{array}{l}\text { - Tổ chức các buổi sinh hoạt cho các em thiếu nhi, diễn } \\
\text { ra vào tối thứ 7 hàng tuần } \\
- \text { Tổ chức văn nghệ đón Tết Trung thu. } \\
- \text { Tổ chức giao lưu văn nghệ kỷ niệm 70 năm cách } \\
\text { mạng tháng Tám và Quốc khánh mùng 2 tháng 9. }\end{array}$ \\
\hline 6 & \begin{tabular}{l} 
Họp bàn các vấn đề về an ninh chính trị, trật tự an toàn \\
\hline
\end{tabular} & Tháng 9 \\
\hline 1
\end{tabular}




\begin{tabular}{|c|c|l|}
\hline & & xã hội do huyện Hạ Hòa phổ biến. \\
\hline 7 & Tháng 10 & $\begin{array}{l}\text { - Hội phụ nữ tổ chức họp thường niên. } \\
- \text { Họp dân cư để nhắc nhở người dân phòng chống trộm, } \\
\text { cắp trong những tháng cuối năm. }\end{array}$ \\
\hline 8 & Tháng 11 & Xét bầu danh hiệu gia đình văn hóa ba năm liền. \\
\hline 9 & Tháng 12 & Tổng kết cuối năm. \\
\hline
\end{tabular}

Nhìn chung lại có thể thấy, hoạt động của nhà văn hóa diễn ra từ năm 2006 đến năm 2015 tập trung vào các hoạt động sau:

\subsubsection{Tổ chức phổ biến đường lối chính sách của Đảng và nhà nước đến nhân dân}

Trong các hoạt động của nhà văn hóa, chức năng tổ chức các cuộc họp phổ biến đường lối, chủ trương nghị quyết của Đảng, nhà nước và các cấp chính quyền là các hoạt động được quan tâm và có hiệu quả nhất. Tại đây, chính quyền địa phương phổ biến đến người dân những chủ trương, đường lối của Đảng, các chính sách cũng như pháp luật của Nhà nước và những quy định của chính quyền địa phương. Các cuộc họp này thường là do trưởng khu chủ trì.

\subsubsection{Tổ chức triển khai các nghị quyết của Đảng và Nhà nước cũng nhu chính quyền địa phuơng}

Nhà văn hoá Hương Xạ là nơi diễn ra các cuộc họp bàn về các chủ trương, các chiến lược xây dựng và phát triển kinh tế địa phương như: Khuyến khích người dân mở rộng sản xuất, mở rộng các ngành nghề kinh doanh, dịch vụ giúp người dân làm giàu chính đáng.

Đây cũng là nơi triển khai các chương trình do Đảng và Nhà nước phát động như: công tác xoá đói giảm nghèo, vận động người dân tích cực áp dụng khoa học kỹ thuật trong lao động, chăm sóc cây trồng và vật nuôi. 
Các chương trình này không được diễn ra thường xuyên, có hoạt động được tiến hành $1 \mathrm{năm} /$ lần, có hoạt động được tiến hành 2 năm/1 lần. Các cuộc họp bàn này thường được diễn ra vào tháng 12 hàng năm và được chia ra làm 2 phần :

+ Phần 1: Lắng nghe bản báo cáo tình hình trong năm vừa qua của cán bộ phụ trách.

+ Phần 2: Cán bộ và nhân dân địa phương họp bàn đề xuất ý kiến sau đó thống nhất đưa ra hướng triển khai trong năm tiếp theo. Nếu có chủ trương của Nhà nước thì cán bộ trong làng sẽ phổ biến người dân rồi nghe ý kiến phản hồi của bà con.

\subsubsection{Tổ chức các cuộc họp thảo luận về các vấn đề liên quan đến cuộc sống của cư dân}

Các cuộc họp thảo luận về các chương trình như: khuyến khích các hộ gia đình thực hành tiết kiệm, đoàn kết tương trợ, giúp đỡ nhau trong cuộc sống cộng đồng,... do chính quyền địa phương và nhân dân tổ chức cũng được diễn ra 1 năm/1 lần tại nhà văn hoá Hương Xạ.

Các nội quy, quy định được người dân thảo luận, bàn bạc đi đến thống nhất như: không thả rông các loại gia súc, gia cầm, vật nuôi; không đốt gạch, đốt rừng khi lúa đang trổ bông; không săn bắt động vật trái phép ;...cũng được tổ chức tại nhà văn hoá Hương Xạ.

Trong các cuộc họp nội bộ được tổ chức tại nhà văn hoá Hương Xạ, cán bộ và nhân dân luôn cùng nhau thảo luận thống nhất đưa ra những quy tắc chung như: Nghiêm cấm hành vi xâm chiếm đất đai của các cá nhân, tập thể dưới mọi hình thức; nghiêm cấm người dân không trồng cây lâu năm, cây có tán rộng trên hành lang đường dây điện cao thế, hạ thế, hành lang giao thông hoặc ranh giới giữa hai khu đất liền kề. Mọi hành vi vi phạm đều phải chịu trách nhiệm và bị xử lý theo quy định nội bộ của địa phương. 


\subsubsection{Tổ chức các cuộc hội họp của các đoàn thể}

Tại nhà văn hoá Hương Xạ, người dân trong làng còn tự tổ chức các buổi giao lưu, nói chuyện nâng cao tình đoàn kết xóm làng như: cùng nhau giải quyết mâu thuẫn giữa các hộ gia đình; cùng nhau thảo luận chọn giống lúa tốt cho mùa vụ tiếp theo; cùng nhau phân công quét dọn đường trong ngày. Tết nguyên đán; cùng nhau bàn bạc đối phó khi có kẻ gian;...Nhờ các cuộc giao lưu, nói chuyện mà người dân trong xã đã biết bảo vệ và giúp đỡ nhau hơn. Các tệ nạn xã hội như: đánh nhau, cãi nhau,...gây mất đoàn kết nội bộ đã có dấu hiệu giảm.

Nhà văn hoá Hương Xạ là nơi Ban Văn hóa Thể thao và Thông tin xã phối hợp với các tổ chức đoàn thể quần chúng nhân dân tổ chức các hoạt động, các phong trào truyền thống như: phong trào thi đua người tốt việc tốt, phong trào thi đua nhà văn hoá,...

Nhà văn hoá Hương Xạ cũng là nơi để Đoàn thanh niên trong khu dân cư thảo luận khi có công việc hay nhiệm vụ cần thiết như: tuyên truyền về an toàn giao thông; phòng, chống tệ nạn xã hội; tích cực tham gia xây dựng nông thôn mới qua việc khởi công các công trình thanh niên,... Là nơi để thiếu nhi tổ chức sinh hoạt hè trong ba tháng: tháng 6 , tháng 7 và tháng 8 . Là nơi để hội Phụ nữ tổng kết chương trình cuối năm (diễn ra 1 nằm 1 lần).

Tại nhà văn hoá Hương Xạ còn tiến hành các buổi họp dân cư, là nơi lấy ý kiến của nhân dân trước cá cuộc bầu cử,... Tại đây cũng diễn ra các buổi họp hướng dẫn người dân về chăn nuôi, trồng trọt, áp dụng khoa học kỹ thuật trong phát triển triển kinh tế, tuyên truyền giáo dục về kỹ năng sống, về đạo đức, lối sống, về sức khỏe và giới tính, về dân số và kế hoạch hóa gia đình.

\subsubsection{Tổ chức các hoạt động kỷ niệm, ngày lễ}

Nhà văn hoá Hương Xạ là nơi triển khai công tác thành lập các đội văn nghệ ở các thôn xóm và tiến hành tổ chức tập luyện, tham gia biểu diễn như: Tổ chức biểu diễn phục vụ chương trình giao lưu mừng Đảng, mừng Xuân đêm 30 Tết và tham gia Lễ hội Đền Mẫu Âu Cơ vào mùng 7 tháng giêng (âm 
lịch) hàng năm, tổ chức chương trình giao lưu kỷ niệm ngày Quốc tế Phụ nữ, ngày thành lập Đoàn TNCS Hồ Chí Minh, chào mừng Đại hội Liên hiệp Thanh niên Việt Nam, chào mừng Mặt trận Tổ quốc xã theo nhiệm kỳ. Nhà văn hóa Hương Xạ còn là nơi tổ chức các đêm giao lưu văn nghệ vào các ngày Lễ, Tết như: Đêm giao thừa, đêm Trăng rằm,....

Nhà văn hoá Hương Xạ cũng thường tổ chức các buổi giao lưu văn hoá văn nghệ nhân kỷ niệm các ngày lễ của dân tộc như: Quốc khánh mùng 2-9, giải phóng miền Nam (30-4),...

Đây còn là nơi tổ chức văn nghệ của các em thiếu nhi trong những ngày lễ như: Tết thiếu nhi (1-6), Rằm trung thu (15-8).

\subsubsection{Tổ chức các cuộc sinh hoạt văn hoá, nghệ thuật}

Nhà văn hóa là một thiết chế văn hóa - giáo dục mang tính tổng hợp nên hoạt động của Nhà văn hóa Hương Xạ khá đa dạng, nội dung và hình thức khá phong phú, phù hợp với tình hình văn hoá, kinh tế, xã hội của địa phương. Tại đây, các hoạt động biểu diễn, hội diễn văn nghệ, thể thao thỉnh thoảng tổ chức đã thu hút đông đảo người dân tham gia.

Nhà văn hoá Hương Xạ là nơi tổ chức các phong trào văn hóa, văn nghệ, thể dục, thể thao như: giao lưu văn nghệ của các chị em trong làng, thi đấu bóng đá, bóng chuyền giữa các làng trong xã,....

Thực hiện lời dạy của Chủ tịch Hồ Chí Minh "khoẻ để lao động và học tập, khoẻ để xây dựng và bảo vệ tổ quốc", tại nhà văn hoá Hương Xạ cũng diễn ra các hoạt động văn hoá, văn nghệ, thể dục, thể thao như: Chương trình giao lưu văn nghệ của chị em trong Hội Phụ nữ thôn; chương trình múa hát mừng xuân mới; chương trình thi đấu bóng chuyền của thanh niên làng Hương Xạ với thanh niên các làng khác trong xã; ...Các chương trình văn hoá, văn nghệ đã làm cho đời sống tinh thần của bà con trong làng được nâng cao.

Nhà văn hoá Hương Xạ là nơi để các em thiếu tổ chức, giao lưu văn nghệ trong các dịp hè, những buổi sinh hoạt của các em thiếu nhi thường diễn ra vào tối chủ nhật hàng tuần trong khoảng thời gian từ ngày 15-6 đến ngày 15-8. 


\subsubsection{Tổ chức các cuộc thi đấu thể dục, thể thao}

Được sự quan tâm, chỉ đạo của Đảng ủy - UBND xã, trong những năm gần đây hoạt động thể dục thể thao của làng Hương Xạ có rất nhiều triển vọng, đặc biệt là các môn thể thao như: bóng chuyền, cầu lông và kéo co đã thu hút được đông đảo người dân địa phương tham gia.

Làng Hương Xạ có một câu lạc được thành lập và duy trì hoạt động từ năm 2006 đến nay, đó là câu lạc bộ bóng chuyền nam. Sân nhà văn hóa Hương Xạ chính là nơi để câu lạc bộ bóng chuyền nam thường xuyên tập luyện để thi đấu. Hàng năm, cán bộ và địa phương trong làng cũng luôn tạo điều kiện cho câu lạc bộ tập luyện và tham gia thi đấu trong các cuộc thi do huyện và xã tổ chức.

Trong 6 tháng đầu mỗi năm, trên địa bàn xã thường có 5 - 6 buổi thi đấu thể thao được tổ chức tại nhà văn hóa Hương Xạ như: Tổ chức giải thể thao mừng Đảng, mừng xuân với một số môn thể thao như: bóng chuyền, cầu lông, kéo co,...

\subsubsection{Các họ̣t động khác}

Nhà văn hóa xã Hương Xạ là nơi phục vụ các hộ gia đình trong làng khi có nhu cầu văn hóa như: Mừng thọ, tiệc cưới, việc tang lễ,...đảm bảo trang trọng không gây mất trật tự công cộng và cần được xem xét cụ thể trước khi sử dụng.

Nhà văn hoá Hương Xạ còn được sử dụng với mục đích như: Tổ chức khánh thành nhà mới, phơi ván bóc cho các xưởng sản xuất ván bóc tại khu dân cư.

Nhìn chung, hoạt động của nhà văn hoá Hương Xạ được sử dụng khá thường xuyên nhưng chủ yếu vẫn là nơi tổ chức hội họp, sinh hoạt cộng đồng của nhân dân. Việc tổ chức các hoạt động tuyên truyền, văn hoá, văn nghệ, thể dục, thể thao và duy trì sinh hoạt các câu lạc bộ, đội văn nghệ quần chúng có được thực hiện tại nhà văn hoá. Việc triển khai, sắp xếp các chương trình hoạt động tại nhà văn hoá Hương Xạ cũng đã thực hiện kịp thời. 


\subsection{Bước đầu đánh giá về hoạt động của nhà văn hóa Hương Xạ}

Nhà văn hóa Hương Xạ trong quá trình hoạt động đã đóng vai trò như là một trung tâm sinh hoạt chính trị và trung tâm sinh hoạt văn hoá. Nhà văn hoá Hương Xạ là nơi tiếp nhận những ý kiến phản hồi của người dân trong các cuộc họp chính quyền, nơi người dân tiếp nhận đường lối, chính sách trong công cuộc xây dựng nông thôn mới từ Trung ương thông qua cán bộ địa phương. Trong thời gian qua, tại nhà văn hóa Hương Xạ, người dân luôn nỗ lực tuân thủ chấp hành và thực hiện đúng chủ trương, đường lối của Đảng và chính sách, pháp luật của Nhà nước đề ra. Tuy nhiên, hiệu quả các hoạt động diễn ra tại nhà văn hóa vẫn mang tính chất nhỏ lẻ, đơn điệu. Hiệu quả sử dụng nhà văn hóa Hương Xạ chỉ mang tính chất đáp ứng nhu cầu của Đảng và Nhà nước đề ra chứ chưa có sự sáng tạo, chưa có sự đổi mới tiến bộ, chưa tạo ra nét riêng biệt.

Nhà văn hóa có một vai trò to lớn trong đời sống sinh hoạt của người dân, đó là địa điểm để người dân hội, họp, nơi tuyên truyền các chủ trương, đường lối, chính sách, pháp luật của Đảng và Nhà nước, là nơi tổ chức các hoạt động vui chơi, giải trí, giao lưu văn hóa, văn nghệ, thể dục, thể thao. Nhà văn hóa là một phần không thể thiếu trong quá trình xây dựng nông thôn mới, có nhà văn hóa thì tinh thần cố kết cộng đồng và các hoạt động sinh hoạt văn hóa của người dân mới được nâng cao. Ngôi nhà văn hóa không chỉ là một không gian sinh hoạt văn hóa mà ở đó còn thể hiện được một kết cấu hạ tầng mới trong thời kỳ hiện đại.

Mặc dù phòng Văn hoá và Thông tin huyện Hạ Hoà đã tham mưu với UBND huyện Hạ Hoà ra văn bản số 955/HD-UBND ngày 27 tháng 8 năm 2014 về việc quản lý và tổ chức các hoạt động nhà văn hóa khu dân cư trên địa bàn Hương Xạ, yêu cầu xã Hương Xạ chỉ đạo khu dân cư 3 thành lập ban quản lý, xây dựng quy chế hoạt động và thường xuyên kiểm tra duy trì các hoạt động của nhà văn hoá Hương Xạ nhưng sau một thời gian thực hiện, ngày 22/8/2015 UBND huyện Hạ Hoà lại ra văn bản số 1145/UBND-VH 
nhằm nâng cao hiệu quả hoạt động, quản lý và sử dụng nhà văn hoá, vì trong quá trình hoạt động nhà văn hoá Hương Xạ vẫn còn những tồn tại, đó là:

1. Việc xây dựng nhà văn hoá Hương Xạ chưa theo đúng tiêu chí xây dựng nhà văn hóa như quy định, xây dựng khá xa trung tâm (chưa đảm bảo tiêu chuẩn đủ 80 chỗ ngồi, có cổng,..), chưa có ban quản lý nhà văn hóa. Việc quản lý nhà văn hóa và tổ chức các hoạt động chính trị, văn hóa thể thao ở đây vẫn mang tính tùy tiện, chưa chuyên nghiệp.

2. Từ tình hình trên dẫn đến hiệu quả sử dụng nhà văn hoá Hương Xạ chưa cao. Tình hình hoạt động tại nhà văn hoá Hương Xạ chủ yếu diễn ra những cuộc họp của các ban, ngành, đoàn thể khu dân cư, tại nhà văn hoá Hương Xạ mỗi tháng chỉ tổ chức một cuộc họp. Tình trạng nhà văn hóa Hương Xạ thường xuyên "đóng cửa" vẫn còn tồn tại, trong các tháng cuối năm, nhà văn hoá Hương Xạ hầu như không có chương trình hay hoạt động nào diễn ra nên thời gian đó xung quanh nhà văn hoá thường để cỏ mọc ưm tùm

3. Nhà văn hoá Hương Xạ được xây dựng từ năm 2006 và năm 2014 cũng đã được chỉnh trang, tu sửa lại nhưng do buông lỏng quản lý nên hiện nay nhà văn hoá Hương Xạ xuống cấp nhanh như: mái nhà, tường nhà,...

4. Cơ sở vật chất bên trong nhà văn hoá Hương Xạ chưa đảm bảo yêu cầu về số lượng và chất lượng: tăng âm, bàn ghế, tranh ảnh tuyên truyền, bảng tin, nội quy hoạt động,... đã cũ kỹ và hư hỏng.

5. Trình độ văn hoá của trưởng khu và phó trưởng khu thấp: trưởng khu và phó trưởng khu chỉ học hết lớp 10 hơn nữa họ chưa được đi học một khoá học nào liên quan đến công tác quản lý và sử dụng nhà văn hoá, chính vì thế việc trưởng khu và phó trưởng khu kiêm luôn việc quản lý nhà văn hóa Hương Xạ là hoàn toàn sai quy định.

6. Nguồn kinh phí hoạt động của nhà văn hoá Hương Xạ ít ỏi,mỗi năm nguồi kinh phí dành cho tất cả các hoạt động văn hoá, văn nghệ, thể dục, thể thao khoảng 5 triệu đồng. 
7. Mặc dù diện tích nhà văn hóa Hương Xạ đã đáp ứng nhu cầu của Đảng và Nhà nước đề ra (tổng diện tích sân, nhà, khuôn viên là trên $300 \mathrm{~m}^{2}$, riêng diện tích nhà văn hóa là $90 \mathrm{~m}^{2}$ ) nhưng không gian của nhà văn hóa lại khá rộng so với số dân hiện đang có ở địa phương.

Bảng: Điều tra tổng quan làng, xã Hương Xạ - năm 2015

\begin{tabular}{|c|c|c|c|}
\hline STT & Mục điều tra & $\begin{array}{c}\text { Xã Hương Xạ } \\
\text { (người) }\end{array}$ & $\begin{array}{c}\text { Làng Hương Xạ } \\
\text { (người) }\end{array}$ \\
\hline 1 & Tổng số dân & 2571 & 298 \\
\hline 2 & Đảng viên & 143 & 15 \\
\hline 3 & Đoàn viên & 235 & 21 \\
\hline 4 & Hội phụ nữ & 401 & 38 \\
\hline 5 & Hội cựu chiến binh & 307 & 24 \\
\hline 6 & Câu lạc bộ bóng chuyền & 13 câu lạc bộ & 1 câu lạc bộ $(21$ \\
& & & người) \\
\hline 7 & Câu lạc bộ bóng đá & 1 & 0 \\
\hline 8 & Câu lạc bộ bóng bàn & 1 & 0 \\
\hline 9 & Câu lạc bộ cầu lông & 3 & 0 \\
\hline
\end{tabular}

\subsection{Những tồn tại của nhà văn hóa Hương Xạ}

Hiện nay, sự phối hợp giữa người dân và ban quản lý nhà văn hoá Hương Xạ chưa chặt chẽ. Ban quản lý nhà văn hoá Hương Xạ còn nhiều bất cập cả về số lượng và chất lượng.

Cán bộ quản lý (trưởng thôn và phó trưởng thôn) nhà văn hoá Hương Xạ thiếu kỹ năng và thiếu trách nhiệm trong công việc quản lý nhà văn hoá, họ chưa được tham gia vào bất kỳ khoá học hướng dẫn cách sử dụng, khai thác nhà văn hoá hiệu quả.

Theo ông Vũ Ngọc Hùng (trưởng khu nhà văn hóa Hương Xạ) cho biết: "Tôi chura tùng được tham gia một khóa đào tạo nào liên quan đến cách sủ dụng nhà văn hóa, chính vì thế tôi không thể biến nhà văn hóa Hương Xạ 
thành một trung tâm sinh hoạt sôi nổi được. Hơn nũa, tôi cũng lón tuổi rồi, bây giờ tôi chỉ muốn lớp trẻ lên làm thay tôi để phát triển ngôi nhà văn hóa Hương Xạ này thành một trung tâm vui chơi giải trí sôi động, nhung hiện tại cũng có ai chịu làm công việc này đâu."

Người dân trong làng Hương Xạ chưa có trách nhiệm trong việc bảo vệ, giữ gìn không gian chung của nhà văn hoá.

Nguồn kinh phí hoạt động dựa vào số tiền đóng góp ít ỏi từ người dân nên không thu hút được người dân tham gia.

Vấn đề quan trọng là hiện nay tình hình kinh tế của người dân làng Hương Xạ còn khó khăn, chính vì thế tỷ lệ người dân di cư ra thành phố học tập và làm việc ngày càng nhiều, điều đó đã làm cho các hoạt động văn hoá, văn nghệ, thể dục, thể thao trong làng không được thực hiện thường xuyên do thiếu nguồn nhân lực trẻ.

Các cán bộ lãnh đạo cấp trên chưa có những quy định chặt chẽ trong việc quản lý và sử dụng nhà văn hoá.

\subsection{Kiến nghị của người dân:}

Đề nghị xã Hương Xạ mở lớp hướng dẫn cách sử dụng nhà văn hoá cho ban quản lý nhà văn hoá Hương Xạ để các hoạt động văn hoá, văn nghệ, thể dục, thể thao diễn ra tại nhà văn hoá Hương Xạ đạt hiệu quả hơn nữa.

Đề nghị UBND tỉnh Phú Thọ, huyện Hạ Hoà và xã Hương Xạ hỗ trợ kinh phí hàng năm để nhà văn hoá Hương Xạ có điều kiện sửa chữa, nâng cấp cả về cơ sở vật chất và trang thiết bị.

Dười đây là một số ý kiến của người dân trong làng: Bà Trần Thị Nga (50 tuổi) đang cư trú tại làng Hương Xạ, cho biết: "Nhà văn hóa Huong Xa có vai trò quan trọng đối với chúng tôi, đây là nơ để chúng tôi tham gia hội họ, lắng nghe đường lối chủ trưong của Đảng,là nơi chúng tôi nêu ý kiến, quan điểm của mình về nhũng vấn đề chung của xã họi, của đất nuớc. Nếu không có nhà văn hóa thì giờ đây chúng tôi chẳng biết họi họp ở đâu nũa”. Bà Trần Thị Nga còn cho biết thêm "Nhà văn hóa Hưong Xạ chủ yếu hoạt 
động theo chưong trình, nội dung của Đảng, Nhà nước và chính quyền địa phuơng đề ra nên tôi đến đây cũng không thuờng xuyên lắm, thường thuờng tôi đến nhà văn hóa khi nhận được thông báo tham gia hội họp tù trương khu. Dù hoạt động không thuoòng xuyên nhung tôi thấy nhà văn hóa vẫn giư một vai trò quan trọng trong đời sống sinh hoạt của chúng tôi

Theo ý kiến của chị Bùi Thị Hồng Hạnh, 23 tuổi, đang là giáo viên trường THCS Hương Xạ, thì: "Có bao giờ tôi thấy được vai trò của nhà văn hóa Huong Xạ đâu, mỗi lần truơng khu gọi đi họ thì bố me tôi thay nhau đi chứ tôi có bao giờ đến đó. Vì thế, đối với cá nhân tôi, tôi không nhận thấy vai trò của nhà văn hóa đối với mình".

Em Nguyễn Thị Ngọc Dung, 13 tuổi đang làng học sinh lớp 8 trường THCS Hương Xạ, em đang cư trú tại làng Hương Xạ, cho biết: "Tù bé đến giò̀, cứ nghỉ hè là em lại được đến nhà văn hóa Huơng Xạ để sinh hoạt hè. Ở đó em thấy vui lắm, có nhiều bạn chơi cùng em nhưng vì đường tù nhà em đến đó xa nên bố me em thỉnh thoảng mới đưa em đii." Thế em thấy có nhiều hoạt động vui chơi ở nhà văn hóa Hương Xạ không? "Không a. Em chỉ thích đến nhà văn hóa để chơi với các bạn em thôi, ngoài Tết Thiếu Nhi và Trung Thu ra, ở nhà văn hóa Hương Xạ có tổ chưc hoạt động vui chơi gì đâu ạ” Em có hay tham gia các chương trình văn hóa, văn nghệ do làng Hương Xạ tổ chức không? "Không chị ở, vì làng em ít tổ chức lắm, nếu có thì cũng chỉ có mấy em bé con giáo viên, con cán bộ trong làng tham gia thôi ạ. Với lại tù bé đến giờ em chura tham gia giao luu văn hóa văn nghệ bao giờ ạ."

\subsection{Các giải pháp nâng cao hiệu quả hoạt động của nhà văn hóa}

Vấn đề đặt ra là làm thế nào để nâng cao trách nhiệm của người dân làng Hương Xạ trong việc: bảo vệ, giữ gìn và khai thác hiệu quả nhà văn hoá Hương Xạ.

Làm thế nào để có nguồn kinh phí hỗ trợ trong việc: tu bổ và tổ chức hoạt động tại nhà văn hoá Hương Xạ? 
Đặc biệt là làm thế nào để: khai thác và sử dụng nhà văn hoá Hương Xạ hiệu quả?

Phuoong hương chung: Tiếp tục tuyên truyền, vận động mọi nguồn lực đẩy mạnh đầu tư xây dựng các thiết chế văn hoá cơ sở nói chung và thiết chế nhà văn hoá Hương Xạ nói riêng theo tiêu chí của bộ VHTT\&DL về xây dựng nông thôn mới.

\section{Một số nhiệm vụ cu thể:}

1. Tiếp tục đẩy mạnh công tác tuyên truyền, nâng cao nhận thức của các cấp Đảng, chính quyền và các tầng lớp nhân dân đối với công tác xã hội hoá trên lĩnh vực văn hoá.

Tiếp tục đẩy mạnh công tác tuyên truyền thông qua các phương tiện thông tin đại chúng để góp phần nâng cao nhận thức của các cấp, các ngành, các đoàn thể và toàn thể người dân làng Hương Xạ trong việc nhận thức đúng vai trò của nhà văn hoá.

Liên tục đề cao vị trí, vai trò, tầm quan trọng của nhà văn hoá Hương Xạ trong đời sống sinh hoạt của người dân; thực hiện hiệu quả chủ trương nâng cao chất lượng hoạt động và hiệu quả sử dụng nhà văn hoá Hương Xạ trong những năm tiếp theo.

Tiếp tục thực hiện tốt phong trào "Toàn dân đoàn kết xây dựng đời sống văn hoá”. Gắn kết chặt chẽ các phong trào với mục tiêu Quốc gia về xây dựng nông thôn mới. Đưa tiêu chí thực hiện tu sửa, chỉnh trang nhà văn hoá Hương Xạ hàng năm vào làm căn cứ để tham gia xét duyệt cuộc thi khu dân cư văn hoá hàng năm.

2. Tăng cường công tác chỉ đạo của chính quyền, sự phối hợp giữa các đoàn thể trong việc thực hiệncông tác quản lý, nâng cao chất lượng hoạt động nhà văn hoá Hương Xạ.

Tăng cường sự chỉ đạo của chính quyền với việc nâng cao chất lượng hoạt động và hiệu quả sử dụng nhà văn hoá Hương Xạ. UBND huyện Hạ Hoà đã chỉ đạo các cơ quan chuyên môn tiến hành kiểm tra, rà soát, hướng dẫn tổ 
chức các hoạt động nhằm nâng cao chất lượng hoạt động của nhà văn hoá Hương Xạ.

Điều chỉnh, bổ sung quy chế hoạt động của nhà văn hoá Hương Xạ, thành lập ban quản lý và cơ chế hoạt động phù hợp nhằm đạt hiệu quả sử dụng cao.

Tăng cường công tác phối hợp giữa chính quyền với nhân dân trong việc triển khai thực hiện nhiệm vụ. Phát huy vai trò của các đoàn thể nhân dân trong việc tuyên truyền các chủ trương của Đảng, chính sách, pháp luật của Nhà nước về các nội dung liên quan đến hoạt động tại nhà văn hoá Hương Xạ. Từ đó, đẩy mạnh công tác xã hội hoá nguồn kinh phí đầu tư nâng cấp, mua sắm trang thiết bị cho nhà văn hoá Hương Xạ để đáp ứng nhu cầu sinh hoạt cộng đồng của người dân trong làng Hương Xạ.

3. Thực hiện tốt công tác xã hội hoá đảm bảo thường xuyên có nguồn kinh phí chỉnh trang, tu sửa nhà văn hoá Hương Xạ.

Tích cực huy động các nguồn vốn xã hội hoá, tranh thủ các nguồn vốn từ ngân sách các cấp, tập trung huy động nguồn lực từ hộ dân cư hàng năm để tiến hành tu sửa, chỉnh trang, nâng cấp, mua sắm trang thiết bị cho các nhà văn hoá Hương Xạ.

Hàng năm căn cứ vào kế hoạch, chương trình cụ thể làng Hương Xạ sẽ tự đóng góp một phần kinh phí để đầu tư cho các hoạt động của nhà văn hoá Hương Xạ.

4. Đánh giá sơ kết, tổng kết cuối năm, thi đua khen thưởng gắn với đánh giá gia đình văn hoá, khu văn hoá và xây dựng chính quyền trong sạch vững mạnh trong năm tiếp theo.

Hàng năm cần tiến hành công tác sơ kết, tổng kết công tác quản lý, nâng cao chất lượng hoạt động và hiệu quả sử dụng nhà văn hoá Hương Xạ vào thời gian cố định trong năm. Lấy tiêu chí tăng cường cơ sở vật chất, công tác phối hợp giữa các ban ngành, đoàn thể để nâng cao chất lượng hoạt động của nhà văn hoá Hương Xạ. 


\section{Tiểu kết}

Nhà văn hoá Hương Xạ có một vai trò quan trọng trong đời sống người dân, nhà văn hoá góp phần đẩy mạnh nếp sống văn hoá - văn minh, góp phần nâng cao hiệu quả các chương trình xây dựng làng văn hoá, gia đình văn hoá ở làng Hương Xạ.

Xây dựng đời sống văn hóa làng Hương Xạ là nội dung quan trọng trong đường lối xây dựng nông thôn mới của Đảng và Nhà nước và luôn được quan tâm chỉ đạo sát sao. Năm 2006, UBND xã Hương Xạ - huyện Hạ Hòa tỉnh Phú Thọ nhận được công văn của cấp trên về việc triển khai xây dựng Nhà văn hóa xã Hương Xạ với mục đích phục vụ nhu cầu của người dân trong thời kỳ đổi mới. Tuy nhiên, bên cạnh những mặt tích cực từ năm 2006 đến nay thì nhà văn hoá vẫn tồn tại những mặt hạn chế, các hoạt động tại nhà văn hoá Hương Xạ diễn ra vẫn mang tính nhỏ lẻ, cán bộ quản lý chưa có nhiệt huyết, chưa có kinh nhiệm. Đó là vấn đề mà Đảng, chính quyền và nhân dân cần suy ngẫm và xem xét lại. 


\section{KẾT LUẬN}

Hương Xạ là một ngôi làng thuộc khu vực trung du miền núi Bắc Bộ, mặc dù đã trải qua hơn 300 năm kể từ khi hình thành đến nay nhưng người dân làng Hương Xạ luôn giữ được những giá trị tốt đẹp như: sự cần cù trong lao động, tình đoàn kết xóm làng,.... Trong đời sống sinh hoạt của người dân làng Hương Xạ, nhu cầu sinh hoạt văn hóa vẫn luôn được họ coi trọng, đó là một yếu tố không thể thiếu trong cuộc sống của họ. Trong những năm gần đây, Đảng và Nhà nước ta đã đưa ra những chủ trương, đường lối, chính sách xây dựng đời sống nông thôn mới trên phạm vi toàn đất nước, năm 2006 làng Hương Xạ đã rất phấn khởi khi được xây dựng một ngôi nhà văn hóa mang tên nhà văn hóa Hương Xạ.

Tuy nhiên, việc khai thác và sử dụng nhà văn hóa vẫn còn nhiều tồn tại cả về hình thức lẫn nội dung, phương thức thực hiện, đó là một sự thật không thể phủ nhận. Không gian nhà văn hóa không được bảo vệ và giữ gìn, hoạt động diễn ra quá ít so với mục tiêu đề ra, người phụ trách nhà văn hóa thiếu trách nhiệm và hiểu biết; người dân thờ $o$, không tích cực.

Nhà văn hóa Hương Xạ đã hoạt động được 10 năm, từ năm 2006 đến nay nhưng hiệu quả sử dụng nhà văn hóa chưa cao, chưa triệt để vẫn đang là vấn đề mà Đảng, Nhà nước, nhân dân đang phải đặt câu hỏi.

Những giải pháp khắc phục tình trạng sử dụng kém hiệu quả của nhà văn hóa khu dân cư đã đưa ra nhưng để thực hiện có hiệu quả không chỉ là nỗ lực của ngành văn hoá mà cần sự quan tâm phối hợp chặt chẽ của tất cả các cấp Đảng uỷ, chính quyền, các ban, ngành, đoàn thể cùng toàn thể nhân dân. 


\section{PHỤ LỤC}

\section{Bản kiểm tra hiện trạng nhà văn hoá khu dân cư năm 2012}

Ngày 7 tháng 8 năm 2012, Uỷ ban Nhân dân xã Huơng Xạ củ đại diện tổ công tác đi kiểm tra hiện trạng nhà văn hoá xã Hương Xạ.

Đại diện tổ công tác kiểm tra của xã Hương Xạ, gồm có:

1. Ông Nguyễn Trường Sơn - Công chức văn hoá xã hội - Tổ trưởng

2. Ông Nguyễn Công Chấn - Chủ tịch Uỷ ban Mặt trận Tổ quốc Thành viên

3. Ông Bùi Tiến Dũng - Công chức địa chính - Thành viên

4. Bà Nguyễn Thị Hải Yến - Công chức tài chính - Thành viên

5. Ông Đặng Việt Hùng - Bí thư Đoàn Thanh niên - Thành viên

6. Bà Nguyễn Thị Thanh Xuân - Chủ tịch Hội Liên hiệp Phụ nữ Thành viên

7. Tạ Quang Triệu - Chủ tịch Hội cựu chiến bỉnh - Thành viên

Đại diện khu dân cư, gồm có:

1. Ông Bùi Đức Lụa - Bí thư chi bộ

2. Ông Vũ Ngọc Hùng - Trưởng khu (trình độ học vấn 10/10)

3. Bà Trịnh Thị Bình - Phó Trưởng khu (trình độ học vấn 9/10)

Sau khi tiến hành kiểm tra hiện trạng nhà văn hoá xã Hương Xạ năm 2012, kết quả thu được như sau:

(1)Hệ thống văn bản:

- Quy chế hoạt động nhà văn hoá: Chưa có

- Quyết định thành lập Ban quản lý nhà văn hoá: Chưa có 
(2)Quy mô và thiết chế nhà văn hoá xã Hương Xạ

Quy mô nhà văn hoá xã Hương Xạ, năm 2012

\begin{tabular}{|c|c|c|}
\hline STT & Danh mục & Nội dung \\
\hline 1 & Diện tích (m2) & $400 \mathrm{~m} 2$ \\
\hline 2 & Nhà văn hoá & $\begin{array}{c}\text { Xây dựng năm 2006, xây cấp } 4 \\
\text { giàn hiên tây. } \\
\text { Diện tích sử dụng } 90 \text { m2 }\end{array}$ \\
\hline 3 & Tường nhà & Quét vôi, còn sử dụng tốt \\
\hline 4 & Mái lợp & Bờ lô \\
\hline 5 & Trần nhà & $\begin{array}{c}\text { Trần nhà bị bị hỏng cần sửa sang } \\
\text { lại }\end{array}$ \\
\hline 6 & Nền nhà & Láng xi măng \\
\hline 7 & Cửa & $\begin{array}{c}\text { Cửa chính } 2 \text { khoang bằng gỗ còn } \\
\text { tốt } \\
\text { Cửa sổ } 3 \text { khoang: } 2 \text { khoang còn } \\
\text { tốt, } 1 \text { khoang hỏng }\end{array}$ \\
\hline 8 & Bờ rào & Chưa xây \\
\hline 9 & Sân & Chưa có \\
\hline 10 & Cổng & Chưa có \\
\hline 11 & Nhà để xe & Chưa có \\
\hline 12 & Nhà vệ sinh & Chưa có \\
\hline 13 & Bồn hoa & Chưa có \\
\hline 14 & Cây xanh & Chưa trồng \\
\hline
\end{tabular}


Thiết chế nhà văn hoá xã Hương Xạ, năm 2012

\begin{tabular}{|c|c|c|}
\hline STT & $\overline{\text { Danh mục }}$ & Nội dung \\
\hline 1 & Tượng Bác & Có \\
\hline 2 & Cờ, sao vàng & Có \\
\hline 3 & Khẩu hiệu & Có \\
\hline 4 & $\begin{array}{c}\text { Pa nô khẩu hiện hai bên } \\
\text { cánh gà }\end{array}$ & Có \\
\hline 5 & $\begin{array}{c}\text { Khẩu hiệu băng rôn } 2 \\
\text { bên tường }\end{array}$ & Chưa có \\
\hline 6 & Khung ảnh tư liệu & Có \\
\hline 7 & Phông, rèm & Có \\
\hline 8 & Bục nói chuyện & Có \\
\hline 9 & $\begin{array}{c}\text { Bảng nội quy nhà văn } \\
\text { hoá }\end{array}$ & Chưa có \\
\hline 10 & Tăng âm loa đài & Có \\
\hline 11 & Đèn chiếu sáng & Có 9 chiếc \\
\hline 12 & Quạt & Có 8 \\
\hline 13 & Bàn ghế & 1 chiếc bàn, 24 ghế băng \\
\hline 14 & Ấm chén & 6 bộ (6 ấm; 36 chén) \\
\hline
\end{tabular}

=>Sau khi kiểm tra, kết quả đánh giá cụ thể như sau: Nhà văn hoá xã Hương Xạ trong năm 2012 đã đáp ứng đủ một số điều kiện cần thiết, tuy nhiên vẫn cần chỉnh trang, tu sửa lại cả về quy mô và thiết chế nhà văn hoá cho đầy đủ hơn. 


\section{Bản kiểm tra hiện trạng nhà văn hoá khu dân cư năm 2013}

Ngày 10 tháng 9 năm 2013, Uỷ ban Nhân dân xã Hương Xạ tiếp tục cử đại diện tổ công tác đi kiểm tra lần 2 hiện trạng nhà văn hoá xã Hưong Xạ.

Đại diện tổ công tác, gồm có:

1. Ông Nguyễn Trường Sơn - Công chức văn hoá xã hội - Tổ trưởng

2. Ông Nguyễn Công Chấn - Chủ tịch Uỷ ban Mặt trận Tổ quốc Thành viên

3. Ông Bùi Tiến Dũng - Công chức địa chính - Thành viên

4. Bà Nguyễn Thị Hải Yến - Công chức tài chính - Thành viên

5. Ông Đặng Việt Hùng - Bí thư Đoàn Thanh niên - Thành viên

6. Bà Nguyễn Thị Thanh Xuân - Chủ tịch Hội Liên hiệp Phụ nữ Thành viên

7. Tạ Quang Triệu - Chủ tịch Hội cựu chiến binh - Thành viên Đại diện khu dân cư, gồm có:

1. Ông Bùi Đức Lụa - Bí thư chi bộ

2. Ông Vũ Ngọc Hùng - Trưởng khu (trình độ học vấn 10/10)

3. Ông Cù Văn Thụ - Phó trưởng khu (trình độ học vấn 10/10)

Sau khi tiến hành kiểm tra hiện trạng nhà văn hoá xã Hương Xạ, kết quả thu được như sau:

(1) Hệ thống văn bản:

- Quy chế hoạt động nhà văn hoá: Chưa có

- Quyết định thành lập Ban quản lý nhà văn hoá đang được triển khai chưa thể hiện bằng văn bản. 
(2)Quy mô và thiết chế nhà văn hoá xã Hương Xạ

Quy mô nhà văn hoá xã Huoong Xạ, năm 2013

\begin{tabular}{|c|c|c|}
\hline STT & Danh mục & Nội dung \\
\hline 1 & Diện tích (m2) & $400 \mathrm{~m} 2$ \\
\hline 2 & Nhà văn hoá & $\begin{array}{l}\text { Xây dựng năm 2006, xây cấp } 4 \\
\text { giàn hiên tây. } \\
\text { Diện tích sử dụng } 90 \mathrm{~m} 2\end{array}$ \\
\hline 3 & Tường nhà & Vôi ve đã cũ cần quét lại \\
\hline 4 & Mái lợp & Mái lợp bờ lô còn sử dụng được \\
\hline 5 & Trần nhà & Trần nhựa \\
\hline 6 & Nền nhà & Láng xi măng \\
\hline 7 & Cửa & $\begin{array}{c}\text { Cửa chính } 2 \text { khoang bằng gỗ còn } \\
\text { tốt } \\
\text { Cửa sổ } 3 \text { khoang: còn tốt }\end{array}$ \\
\hline 8 & Bờ rào & Chưa có, cần làm ngay \\
\hline 9 & Sân & Chưa có \\
\hline 10 & Cổng & Chưa có \\
\hline 11 & Nhà để xe & Chưa có \\
\hline 12 & Nhà vệ sinh & Chưa có \\
\hline 13 & Bồn hoa & Chưa có \\
\hline 14 & Cây xanh & Đã trồng \\
\hline
\end{tabular}


Thiết chế nhà văn hoá xã Huơng Xạ, năm 2013

\begin{tabular}{|c|c|c|}
\hline STT & Danh mục & Nội dung \\
\hline 1 & Tượng Bác & Có \\
\hline 2 & Cờ, sao vàng & Có \\
\hline 3 & Khẩu hiệu & Thay đổi \\
\hline 4 & $\begin{array}{l}\text { Pa nô khẩu hiện hai bên } \\
\text { cánh gà }\end{array}$ & Thay đổi \\
\hline 5 & $\begin{array}{c}\text { Khẩu hiệu băng rôn } 2 \\
\text { bên tường }\end{array}$ & Chưa có \\
\hline 6 & Khung ảnh tư liệu & Có \\
\hline 7 & Phông, rèm & Có \\
\hline 8 & Bục nói chuyện & Có \\
\hline 9 & $\begin{array}{c}\text { Bảng nội quy nhà văn } \\
\text { hoá }\end{array}$ & Có \\
\hline 10 & Tăng âm loa đài & Bị hỏng, cần sửa ngay \\
\hline 11 & Đèn chiếu sáng & Có 6 chiếc còn sử dụng tốt \\
\hline 12 & Quạt & Có 8 chiếc: 6 tốt, 2 hỏng \\
\hline 13 & Bàn ghế & $\begin{array}{c}1 \text { chiếc bàn, } 24 \text { ghế băng: cần sơn } \\
\text { và sửa chữa lại }\end{array}$ \\
\hline 14 & Âm chén & 6 bộ (6 ấm; 36 chén) \\
\hline
\end{tabular}

=>Sau khi kiểm tra năm 2013, kết quả đánh giá cụ thể như sau: Nhà văn hoá xã Hương Xạ năm 2013 đã đáp ứng đủ một số điều kiện cần thiết, đã tu 
sửa lại một số yêu cầu đặt ra từ năm 2012, tuy nhiên vẫn cần chỉnh trang, tu sửa lại cả về quy mô và thiết chế nhà văn hoá cho đầy đủ hơn.

\section{Bản kiểm tra hiện trạng nhà văn hoá khu dân cư năm 2014}

Ngày 19 tháng 8 năm 2013, Uỷ ban Nhân dân xã Hương Xạ tiếp tục cư đại diện tổ công tác đi kiểm tra lần 3 hiện trạng nhà văn hoá xã Huơng Xạ.

Đại diện tổ công tác, gồm có:

1. Ông Nguyễn Trường Sơn - Công chức văn hoá xã hội - Tổ trưởng

2. Ông Nguyễn Công Chấn - Chủ tịch Uỷ ban Mặt trận Tổ quốc Thành viên

3. Ông Bùi Tiến Dũng - Công chức địa chính - Thành viên

4. Bà Nguyễn Thị Hải Yến - Công chức tài chính - Thành viên

5. Ông Đặng Việt Hùng - Bí thư Đoàn Thanh niên - Thành viên

6. Bà Nguyễn Thị Thanh Xuân - Chủ tịch Hội Liên hiệp Phụ nũ Thành viên

7. Tạ Quang Triệu - Chủ tịch Hội cựu chiến binh - Thành viên Đại diện khu dân cư, gồm có:

1. Ông Bùi Đức Lụa - Bí thư chi bộ

2. Ông Vũ Ngọc Hùng - Trưởng khu (trình độ học vấn 10/10)

3. Ông Cù Văn Thụ - Phó trưởng khu (trình độ học vấn 10/10)

Sau khi tiến hành kiểm tra hiện trạng nhà văn hoá xã Hương Xạ, kết quả thu được như sau:

(1)Hệ thống văn bản:

-Quy chế hoạt động nhà văn hoá xã Hương Xạ: có nội quy, văn bản quy chế đang thảo luận chỉnh sửa vẫn chưa phổ biến đến người dân

-Quyết định thành lập Ban quản lý nhà văn hoá: đã có quyết định nhưng chưa thể hiện bằng văn bản. 
(2)Quy mô và thiết chế nhà văn hoá xã Hương Xạ

Quy mô nhà văn hoá xã Hương Xạ, năm 2014

\begin{tabular}{|c|c|c|}
\hline STT & Danh mục & Nội dung \\
\hline 1 & Diện tích (m2) & $400 \mathrm{~m} 2$ \\
\hline 2 & Nhà văn hoá & $\begin{array}{c}\text { Xây dựng năm 2006, xây cấp } 4 \\
\text { giàn hiên tây. } \\
\text { Diện tích sử dụng } 90 \text { m2 }\end{array}$ \\
\hline 3 & Tường nhà & Vôi ve đã cũ cần quét lại \\
\hline 4 & Mái lợp & $\begin{array}{c}\text { Mái lợp bờ lô có } 2 \text { chỗ vỡ nhưng } \\
\text { vẫn còn sử dụng được }\end{array}$ \\
\hline 5 & Trần nhà & Trần nhựa \\
\hline 6 & Nền nhà & Lát gạch \\
\hline 7 & Cửa & $\begin{array}{c}\text { Cửa chính } 2 \text { khoang bằng gỗ còn } \\
\text { tốt } \\
\text { Cửa sổ } 3 \text { khoang: còn tốt }\end{array}$ \\
\hline 8 & Bờ rào & Chưa có, cần làm ngay \\
\hline 9 & Sân & Đổ bê tông $100 \mathrm{~m} 2$ \\
\hline 10 & Cổng & Chưa có \\
\hline 11 & Nhà để xe & Chưa có \\
\hline 12 & Nhà vệ sinh & $\begin{array}{c}\text { Đã có (1 nhà vệ sinh nam, } 1 \text { nhà } \\
\text { vệ sinh nữ) }\end{array}$ \\
\hline 13 & Bồn hoa & Đã trồng \\
\hline 14 & Cây xanh & Đã trồng \\
\hline
\end{tabular}


Thiết chế nhà văn hoá xã Hương Xạ, năm 2014

\begin{tabular}{|c|c|c|}
\hline STT & Danh mục & Nội dung \\
\hline 1 & Tượng Bác & Có \\
\hline 2 & Cờ, sao vàng & Có \\
\hline 3 & Khẩu hiệu & Có \\
\hline 4 & $\begin{array}{c}\text { Pa nô khẩu hiện hai bên } \\
\text { cánh gà }\end{array}$ & Có \\
\hline 5 & $\begin{array}{c}\text { Khẩu hiệu băng rôn } 2 \\
\text { bên tường }\end{array}$ & Có \\
\hline 6 & Khung ảnh tư liệu & Có \\
\hline 7 & Phông, rèm & Có \\
\hline 8 & Bục nói chuyện & Có \\
\hline 9 & $\begin{array}{c}\text { Bảng nội quy nhà văn } \\
\text { hoá }\end{array}$ & Có \\
\hline 10 & Tăng âm loa đài & Bị hỏng, cần sửa ngay \\
\hline 11 & Đèn chiếu sáng & Có 9 chiếc \\
\hline 12 & Quạt & Có 8 chiếc \\
\hline 13 & Bàn ghế & 1 chiếc bàn, 24 ghế băng \\
\hline 14 & Âm chén & 10 bộ (10 ấm; 100 chén) \\
\hline
\end{tabular}

=>Sau khi kiểm tra, kết quả đánh giá của tổ công tác như sau:

Ưu điểm: Tại nhà văn hoá xã Hương Xạ đã đầu tư xây dựng tương đối đầy đủ hạng mục công trình. Các thiết chế trong nhà văn hoá xã hương Xạ cũng đã đầy đủ. 
Nhược điểm: Nhà văn hoá xã Hương Xạ còn thiếu diện tích khuôn viên bên ngoài và chưa có rào xung quanh.

Ý kiến đề xuất của khu dân cu là: Đề nghị các cấp có thẩm quyền hỗ trợ kinh phí tu sửa nâng cấm thêm một số thiết chế. Đề nghị UBND xã Hương Xạ điều chỉnh thêm đất (nếu có) để đảm bảo xây dựng khuôn viên nhà văn hoá. 


\section{TÀI LIỆU THAM KHẢO}

1. Nguyễn Quang Ngọc (2007). Tiến trình lịch sử Việt Nam. NXB Giáo dục

2. Vũ Ngọc Khánh (2008). Làng Văn hóa cổ truyền Việt Nam. NXB Văn học

3. Toan Ánh (2001). Nếp cũ. NXB Trẻ.

4. Trần Quốc Vượng. Văn hóa Việt Nam tìm tòi và suy nghĩ, NXB Văn hóa dân tộc.

5. Trần Quốc Vượng (2001). Cơ sở văn hóa Việt Nam, NXB Giáo dục.

6. Ngô Thị Kim Doan (2004). Văn hóa làng xã Việt Nam, NXB Văn hóa thông tin.

7. Đặng Thị Vân Chi. Tập bài giảng "Làng Xã Việt Nam".

8. TTXVN. (2015). Việt Nam đất nước con người - thành tựu 70 năm xây dựng và phát triển (1945-2015). NXB Thông tấn.

9. Phạm Minh Chính, Vương Quân Hoàng. (2009). Kinh tế Việt Nam: Thăng trầm và đột phá. NXB Chính trị quốc gia, Hà Nội.

10. Nguyễn Đức Thành. Đối diện thách thức tái cơ cấu kinh tế. NXB Đại học quốc gia Hà Nội.

11. Bộ Văn hóa, Thể thao và Du lịch. (2013). Thực trạng, giải pháp xây dựng nền văn hóa Việt Nam trong thời kỳ đổi mới. Kỷ yếu hội thảo, tổ chức tại Ban VHTTDL ngày 15-52013.

12. Nguyễn Thị Thơm. Nghiên cứu ảnh hưởng của Phật giáo đối với người Việt hiện nay. Học viện Phật giáo Việt Nam.

13. Ngô Đức Thịnh. Tín ngưỡng và văn hóa tín ngưỡng ở Việt Nam. NXB Trẻ. 